Chapter 11

\title{
Production of Anthocyanins in Grape Cell Cultures: A Potential Source of Raw Material for Pharmaceutical, Food, and Cosmetic Industries
}

\author{
Anthony Ananga, Vasil Georgiev, Joel Ochieng, \\ Bobby Phills and Violeta Tsolova \\ Additional information is available at the end of the chapter \\ http://dx.doi.org/10.5772/54592
}

\section{Introduction}

Research continues to show that many artificial pigments are actually detrimental to our health. According to [1], there is an increasing consumer preference for healthy foods, which has invited considerable demand for the use of anthocyanins as natural colorants, because of their natural pedigree and healthful properties. Anthocyanins are the most widely distributed group of water-soluble plant pigments in nature. They are mainly responsible for the mauve, red, blue, and purple colors in flowers, fruits, leaves, seeds and other organs in most of the flowering plants. The other important class of water-soluble pigments are betalains, which are present only in plants belonging to 13 families of Caryophyllales order [2-5]. An interesting phenomenon is the existence of mutual exclusiveness of anthocyanins and betalains in plant kingdom [3, 5-9]. Recent research demonstrated that simultaneous production of anthocyanins and betalains is possible in cell cultures and seedlings of anthocyanin producing plants by introduction and expression of genes encoding dihydroxyphenylalanine (L-DOPA) dioxygenases in combination with substrate precursor feeding [10]. However, the co-occurrence of both pigments in the same plant species have never been found in nature and the plants which produce anthocyanins never produce betalains and vice versa [6]. The commercial production of anthocyanin pigments is one of the fastest growing segments of the food colorant industry $[2,11]$. The only industrial sources for anthocyanin pigments are from whole plant extracts [1], with the most common source being grape skins from the wine industry. According to [1], the demand of natural colorants continues to rise by $5-15 \%$ every year and this translated to the sales of anthocyanins isolated from grape skins in 2002, which was estimated to be US $\$ 200$ million worldwide. The increase 
in demand for processed foods and high health products has caused the manufacturers to look for alternative sources of colorants with antioxidant properties. One source is the production of anthocyanins through the use of plant cell cultures [2,12,13].

Anthocyanins are synthesized via the flavonoid pathway, and they are known to contribute red, blue and purple color to colored grapes, wines and other products [14-18]. Anthocyanins can be used not only as food and beverage additives to obtain attractive natural coloration [19], but also for generating pharmaceutical and cosmetic products. Most researchers are optimistic about utilizing them as bioactive compounds with the consideration that they have the potential to improve human health [1]. Anthocyanins have been implicated in lowering the risk of cardiovascular disease and certain cancers. Dietary anthocyanins can be obtained by humans through the ingestion of fresh colored fruits processed into food and beverages. For instance, the consumption of red grapes and wine is considered vital for bioavailable anthocyanins [20, 21]. To date, most anthocyanin colorants are extracted from grape skins, black carrots, red cabbage, and sweet potato [11]. However, researchers are also exploring the idea of cultivating plant cell cultures for the production of natural colorants. Therefore, there is an interest in improving the quantity and quality of anthocyanins produced in grape cells, and this means that commercially viable systems must be developed to produce anthocyanins in grape cell cultures.

Production of anthocyanins by plant cell cultures is a feasible technology being pursued by industrial and academic interests. Several strategies are being used to enhance anthocyanin biosynthesis in plant cells. This involves a proper selection of the cell strain and optimization of media as well as culture conditions. It is crucial to note that anthocyanins obtained directly from fresh plant materials has limitations such as low metabolite yield, variability, and seasonal availability of raw materials, fresh material losses, inconsistent product quality, and pigment degradation caused by storage and extraction process [22]. Therefore, it is prudent to use in vitro cell and tissue cultures for the production of anthocyanins as the potential alternative to synthetic coloring agents. In order to cultivate plant cell tissues using biological techniques, there needs to be two approaches; 1 ) cell cultures have to be studied, and 2) clonal propagation techniques have to be developed. According to [23], the study of cell cultures starts when the calli are initiated in vitro, for the purpose of finding the optimum media composition that best suits cultivation. It is important to note that during cultivation process, the calli can undergo somaclonal variation as they go through different steps of subculture. However, single lines needs to be screened when the genetic stability is reached, so that the productivity of each cell line can be evaluated with the purpose of using them in cell suspension cultures. In that regard, the production of anthocyanins can be increased in cell suspensions through different ways. The final step is the bioreactor cultivation and scale-up to commercial production of anthocyanins. The last one is a critical step since it is in direct correlation with the economical feasibility of the entire process. In our laboratory, we have more than 10 years experience with in vitro cultures of different Native American grape species. We have various types of cell suspensions, obtained from the super-epidermal cells of muscadine berry skins (Noble var.) at two phonological stages: veraison and physiological maturity. The long-term goal of our research is to use these cells for nutraceuticals, cosmeceuticals, and food additive studies. 


\section{Biology and chemistry of anthocyanins as pigments}

As colored molecules, anthocyanins play a key role in survival and evolution of flowering plants by attracting pollinators, frugivores and seed dispersers on one hand, and by repelling herbivores and parasites on the other [24-26]. Moreover, anthocyanins execute several important physiological functions in plant cells, and their biosynthesis is strongly induced by biotic and abiotic stress factors. These factors include, light, UV radiation, high or low temperatures, wounding, osmotic stress, nutrient imbalance, ozone exposure, herbivores, microbial and viral attacks. In [24, 27] the major roles of anthocyanins in photoprotection of chloroplasts from photoinhibitory damage have been discussed in details. The authors have also clarified the involvement of anthocyanins in protection from UV-B radiation, as well as how anthocyanins decrease oxidative stress by scavenging free radicals and modulating reactive oxygen signaling cascades. These cascades are responsible for triggering the expression of stress-responsive genes as well as the regulation of plant growth and development [24, 27].

Structurally anthocyanins are substituted glycosides and acylglycosides of 2-phenylbenzopyrilium salts (anthocyanidins). The basic structure of anthocyanidins consist of a chromane ring (C-6 - ring A and C-3 - ring C) bearing a second aromatic ring (C-6 - ring B) in position 2 (Figure 1) [2, 5, 28-30]. The various anthocyanidins differs in number and position of the hydroxyl and /or methyl ether groups attached on 3, 5, 6, 7, 3', 4' and/or 5' positions. Despite the fact that 31 different monomeric anthocyanidins have been identified (including 3-deoxyanthocyanidins, pyranoanthocyanidins and sphagnorubins), $90 \%$ of the naturally occurring anthocyanins are based on only six structures (30\% on cyanidin $2,22 \%$ on delphinidin 3 , $18 \%$ on pelargonidin 1 and in summary $20 \%$ on peonidin 4 , malvidin 6 and petunidin 5 ). Those six anthocyanidins are usually known as common anthocyanidins (Figure 1.) [29].

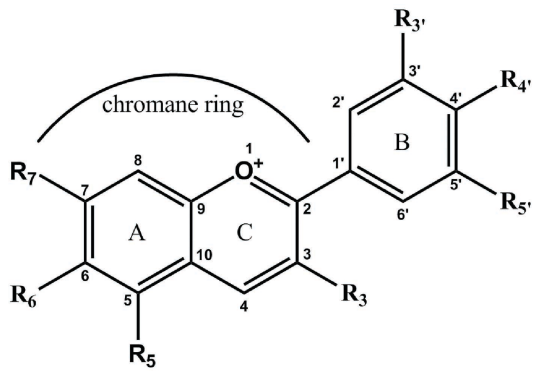
1 Pelargonidin (Pg) $\quad \mathbf{R}_{\mathbf{3}}=\mathrm{OH} ; \mathbf{R}_{\mathbf{5}}=\mathrm{OH} ; \mathbf{R}_{\mathbf{6}}=\mathrm{H} ; \mathbf{R}_{\mathbf{7}}=\mathrm{OH} ; \mathbf{R}_{\mathbf{3}^{\prime}}=\mathrm{H} ; \mathbf{R}_{\mathbf{4}^{\prime}}=\mathrm{OH} ; \mathbf{R}_{\mathbf{5}^{\prime}}=\mathrm{H}$
2 Cyanidin (Cy) $\quad \mathbf{R}_{\mathbf{3}}=\mathrm{OH} ; \mathbf{R}_{\mathbf{5}}=\mathrm{OH} ; \mathbf{R}_{\mathbf{6}}=\mathrm{H} ; \mathbf{R}_{\mathbf{7}}=\mathrm{OH} ; \mathbf{R}_{\mathbf{3}^{\prime}}=\mathrm{OH} ; \mathbf{R}_{\mathbf{4}}=\mathrm{OH} ; \mathbf{R}_{\mathbf{5}^{\prime}}=\mathrm{H}$
3 Delphinidin (Dp) $\quad \mathbf{R}_{\mathbf{3}}=\mathrm{OH} ; \mathbf{R}_{\mathbf{5}}=\mathrm{OH} ; \mathbf{R}_{\mathbf{6}}=\mathrm{H} ; \mathbf{R}_{\mathbf{7}}=\mathrm{OH} ; \mathbf{R}_{\mathbf{3}}=\mathrm{OH} ; \mathbf{R}_{\mathbf{4}}=\mathrm{OH} ; \mathbf{R}_{\mathbf{5}}=\mathrm{OH}$
4 Peonidin $(\mathrm{Pn}) \quad \mathbf{R}_{\mathbf{3}}=\mathrm{OH} ; \mathbf{R}_{\mathbf{5}}=\mathrm{OH} ; \mathbf{R}_{\mathbf{6}}=\mathrm{H} ; \mathbf{R}_{7}=\mathrm{OH} ; \mathbf{R}_{\mathbf{3}^{\prime}}=\mathrm{OMe} ; \mathbf{R}_{\mathbf{4}}=\mathrm{OH} ; \mathbf{R}_{\mathbf{5}^{\prime}}=\mathrm{H}$
5 Petunidin ( $\mathrm{Pt}) \quad \mathbf{R}_{\mathbf{3}}=\mathrm{OH} ; \mathbf{R}_{\mathbf{5}}=\mathrm{OH} ; \mathbf{R}_{\mathbf{6}}=\mathrm{H} ; \mathbf{R}_{\mathbf{7}}=\mathrm{OH} ; \mathbf{R}_{\mathbf{3}^{\prime}}=\mathrm{OMe} ; \mathbf{R}_{\mathbf{4}}=\mathrm{OH} ; \mathbf{R}_{\mathbf{5}^{\prime}}=\mathrm{OH}$
6 Malvidin (Mv) $\quad \mathbf{R}_{\mathbf{3}}=\mathrm{OH} ; \mathbf{R}_{\mathbf{5}}=\mathrm{OH} ; \mathbf{R}_{\mathbf{6}}=\mathrm{H} ; \mathbf{R}_{\mathbf{7}}=\mathrm{OH} ; \mathbf{R}_{\mathbf{3}^{\prime}}=\mathrm{OMe} ; \mathbf{R}_{\mathbf{4}}=\mathrm{OH} ; \mathbf{R}_{\mathbf{5}^{\prime}}=\mathrm{OMe}$

Figure 1. Structures of common anthocyanidins 
The color of anthocyanidins differs with the number of hydroxyl groups, attached on their molecules (especially those substituted in ring B). With the increase of attached hydroxyl groups, the visible color of entire molecule shift from orange to violet (Figure 2) [2, 5, 29, 30]. Glycosylation of anthocyanidins results to additional reddening of obtained anthocyanins, whereas the presence of aliphatic or aromatic acyl moieties causes no color change or slight blue shift and has significant effect on their stability and solubility [5]. Changes in $\mathrm{pH}$ can also cause reversible structural transformations in anthocyanins molecules, which has a dramatic effect on their color (Figure 3) [30-34].

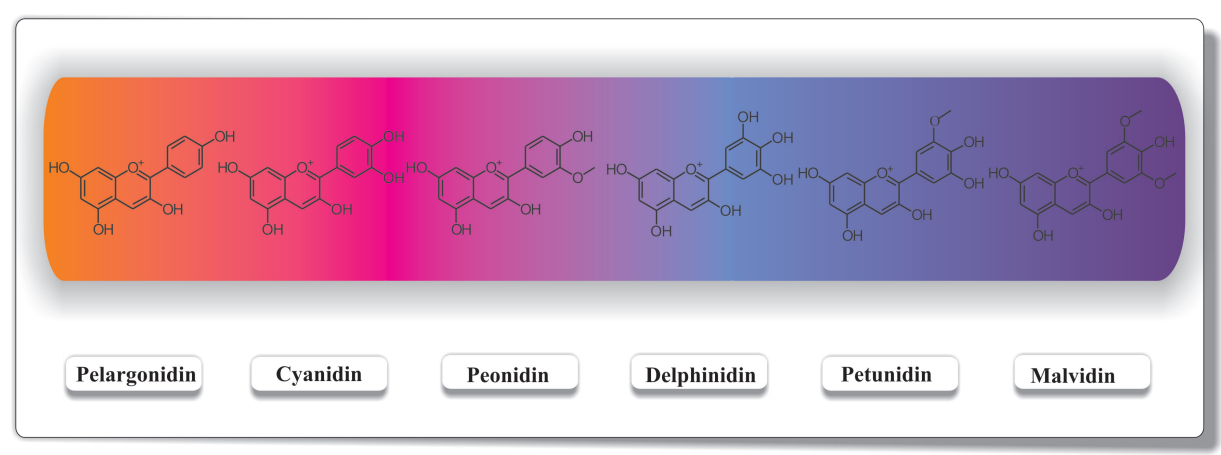

Figure 2. Visible color range of common anthocyanidins

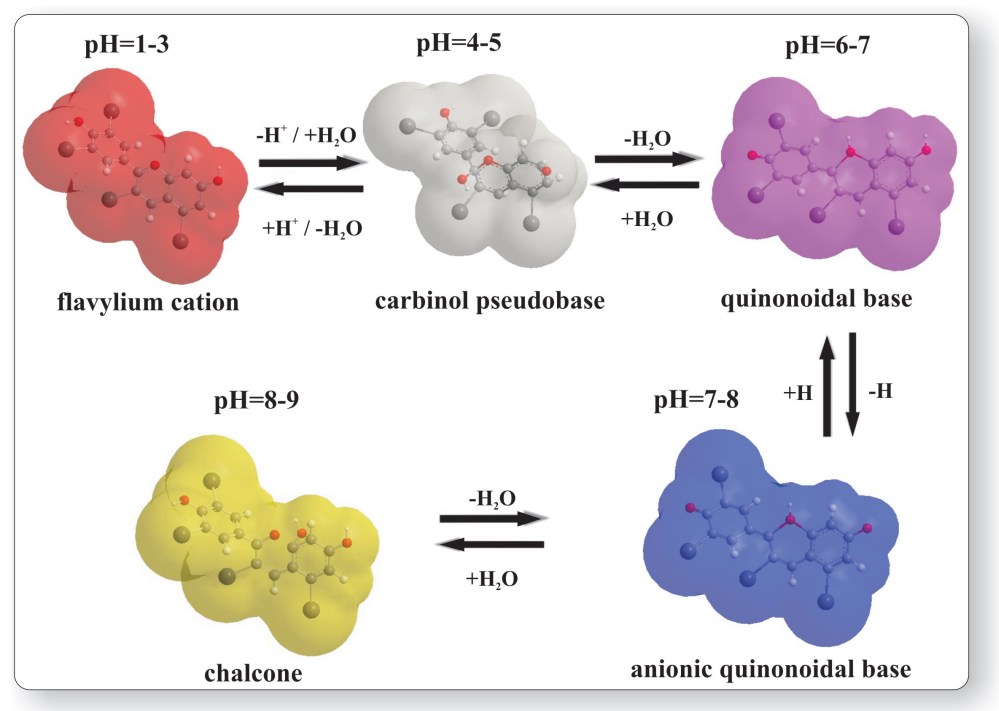

Figure 3. Structural transformations of anthocyanins in aqueous medium with different $\mathrm{pH}$. 
Most of the anthocyanins are $O$-glycosylated at 3 (except those based on 3-deoxyanthocyanidins and sphagnorubinns), 5 or 7 positions and in some cases at $3^{\prime}, 4^{\prime}$ and $5^{\prime}$ positions [24, 35]. However, 8-C-glycosylanthocyanins have been found only in Tricyrtis formosana Baker $[36,37]$. Anthocyanins contain two, one or tree monosaccharide units in their molecules. The usual monosaccharide residues are glucose, galactose, arabinose, ramnose, xylose and glucuronic acid. However, anthocyanins containing disaccharides and trisaccharides were also found in nature but no tetrasaccharides have been discovered yet [24]. Different anthocyanins based on cyanidin 2 aglycone, found in nature are presented on Figure 4

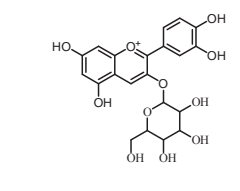

7 Cyanidin-3-O-monoglucoside

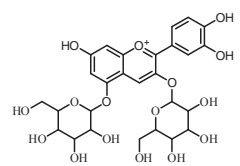

8 Cyanidin-3,5-O-diglucoside

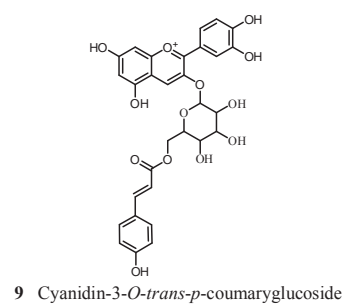

Figure 4. Anthocyanins based on cyanidin aglycone.

\subsection{Anthocyanin biosynthesis in grapes}

As a major flavonoid group, anthocyanins are products of phenylpropanoid metabolism of plant cells $[28,29,38]$. Anthocyanins in grapes are synthesized via flavonoid pathway. The biosynthetic pathway can be divided into two sections, the basic flavonoid upstream pathway, which includes early biosynthetic genes (EBGs), and the specific anthocyanin downstream branch, which includes late biosynthetic genes (LBGs) (Figure 5). Studies have shown that the basic flavonoid upstream pathway is restricted in many plants [39, 40, 41, 42] and that large gene families encodes the enzymes that act early in the flavonoid pathway, while the enzymes acting late in the pathway are encoded by single active gene [43]. The flavonoid pathway starts with phenylalanine, produced via shikimate pathway and transformed to 4-coumaroyl-CoA. The key enzyme, chalcone synthase (CHS) produce a naringenin chalcone by condense of one molecule 4-coumaroyl-CoA and three malonyl-CoA molecules (derived from citrate produced by The Krebs cycle) (Figure 5) [44]. In this case, the rings $\mathrm{A}$ and $\mathrm{C}$ are derived from the acetate pathway, whereas the ring $\mathrm{B}$ is derived from shikimate pathway [45]. Currently, there are three genes encoding $\mathrm{CHS}$ in grapes: Chs1(AB015872), Chs 2 (AB066275), and Chs 3 (AB066274), which are transcribed under different controls $[46,47]$. The three genes act to synthesize naringenin chalcone, which is used in the formation of anthocyanins, proanthocyanidins, and other phenolic compounds. According to [47], the three different CHSs may act in three different pathways to produce different secondary metabolites. In the next step, chalcone isomerase (CHI) converts stereospecifically the naringenin chalcone to its isomer naringenin. Ring $\mathrm{B}$ of the naringenin undergoes further hydroxylation by the enzymes flavonoid $3^{\prime}$-hydroxylase $\left(\mathrm{F} 3^{\prime} \mathrm{H}\right)$, flavonoid 3'5'-hydroxylase $\left(\mathrm{F3}^{\prime} 5^{\prime} \mathrm{H}\right)$ or flavanon 3ß-hydroxylase $(\mathrm{F} 3 \mathrm{H})$ [48]. Then, the obtained dihydroflavonols are reduced by the enzyme dihydroflavonol 4-reductase (DFR) to the corresponding leucoanthocyanidins. 


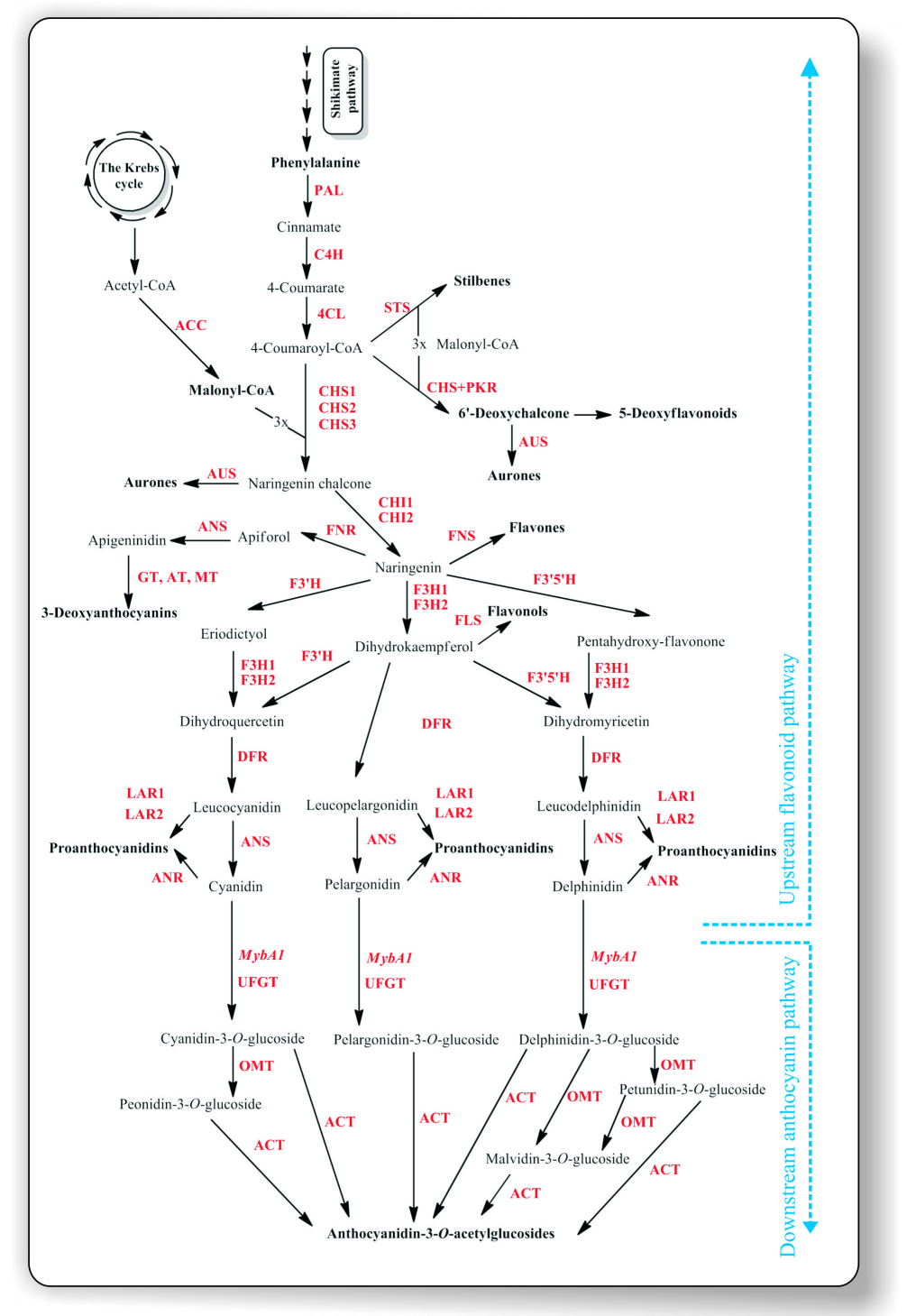

Figure 5. Flavonoids biosynthetic pathways and biosynthetic pathway of anthocyanins in grape: PAL - phenylalanine ammonia-lyase; $C 4 \mathrm{H}$ - cinnamate 4-hydroxylase; $4 \mathrm{CL}$-4-coumarate:CoA ligase; ACC - acetyl-CoA carboxylase; STS - stilbene synthase; CHS1, CHS2, and CHS3 - chalcone synthase 1, 2, and 3, respectively; PKR-polyketide reductase; AUS-aureusidin synthase; CHI1 and CHI2 - chalcone isomerase 1 and 2, respectively; FNS - flavone synthaes; FNR-flavonone 4-reductase; ANS-anthocyanidin synthase; GT-glucosyltransferases; AT - acyltransferases; MT - methyltransferases; F3'H - flavonoid 3'-hydroxylase; F3'5'H-flavonoid 3'5'-hydroxylase; F3H1 and F3H2-flavanon $3 \beta$-hydroxylase 1 and 2, respectively; FLS-flavonol synthase; DFR - dihydroflavonol 4-reductase; LAR1 and LAR2 - leucoanthocyanidin reductase 1 and 2, respectively; ANR-anthocyanidin reductase; MybA 1 - MYB transcription factorgene [49]; UFGT-UDP-glucose: anthocianidin: flavonoid glucosyltransferase; OMT-O-methyltransferase; $\mathrm{ACT}$-anthocyanin acyltransferase. 
After this reduction, anthocyanidin synthase (ANS) oxidize leucoanthocyanidins to their corresponding anthocyanidins. Anthocyanidins are inherently unstable under physiological conditions and were immediately glycosylated to anthocyanins by UDP-glucose: Anthocianidin: Flavonoid glucosyltransferase (UFGT) [48]. Anthocyanins, containing methylated anthocyanidins (peonidin 4, petunidin 5 and malvidin 6) as aglycone can be obtained by methylation of hydroxyl groups on the ring $\mathrm{B}$ of the cyanidin-3-O-glucoside 7, delphinidin-3-O-glucoside and petunidin-3-O-glucoside by the enzyme $O$-methyltransferase (OMT). Future acylation of produced anthocyanins is possible by the action of different anthocyanin acyltransferases (ACT).

\subsection{Anthocyanins storage in grape cells}

Once anthocyanins have been produced, they are transported and stored into the cell vacuole. Inside of vacuole, anthocyanins could be connected to specific proteins forming nomembrane intravacuolar bodies, known as anthocyanic vacuolar inclusions (AVI) (Figure 6) [50]. It has been confirmed that AVI plays a critical role in formation of color in flowering plants [50]. Recently, AVI from grape cell suspension were isolated and analyzed [51]. In contradiction with other plants, it was demonstrated that in grape cell suspension AVI consist of complex mix of tannins, anthocyanins (predominantly acylated derivates), proteins and other organic compounds, encased by lipid membrane $[32,51]$. It was observed that a strong correlation between the prevalence of AVI structures in grapevine cell suspensions and the increase of their anthocyanin accumulation exist [51]. However, the enhancement of AVI prevalence does affect neither the number of available pigmented cells nor the overall growth rate of suspension cultures. Since AVI plays an important function in the storage and concentration of anthocyanins in cell vacuoles, their perspective role as enhancers of anthocyanin accumulation in grape cell suspensions have been proposed [51].

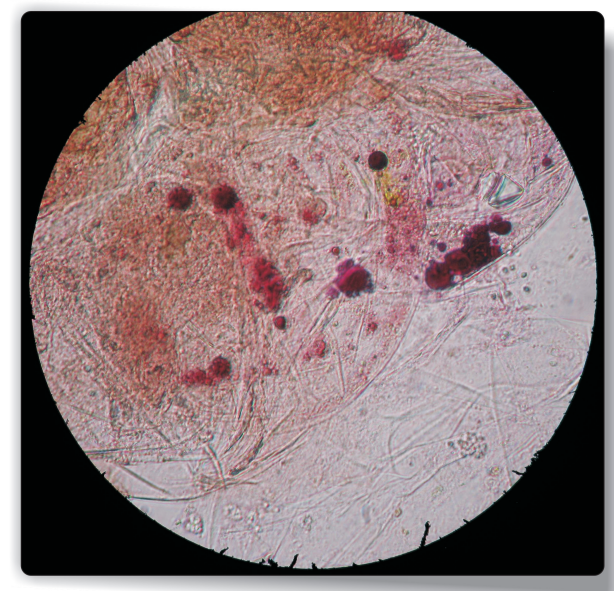

Figure 6. Anthocyanic vacuolar inclusions (AVI) in cell vacuoles of muscadine callus culture. 


\subsection{Characterization of anthocyanins in grapes}

Grapes are rich sources of anthocyanins and bioavailable flavonoids. Grapevines are one of the world's most grown economically important fruit crops. Currently, there are more than 10000 grape cultivars deposited in germplasm collection $[52,53]$. Among them, the cultivars of Vitis vinifera L. and Muscadinia rotundifolia (Michx.) Small., are the most important grapes in Europe and United States, respectively [48]. As a result of crop domestication, numerous changes in grapevine genome have occurred, leading to great variation in berry color [54]. Great differences exist between the vine varieties determined by the presence or absence of anthocyanins in their berries, as well as due to the different anthocyanin compositions of colored berries. It was found that retrotransposon-induced mutations in Myb-related Vvmy$b A 1$ gene are responsible for appearance of white-fruited Vitis varieties [54-56]. The color of grape berries are unique based on the anthocyanin accumulation, and it can be used as "fingerprint" for variety recognition [57]. Thus, Vitis vinifera L. varieties produce only anthocyanidin-3-O-monoglucosides, anthocyanidin-3-O-acetylglucosides and anthocyanidin-3-Op-coumarylglucosides, whereas the other Vitis species and hybrids produce also anthocyanidin-3,5-O-diglucosides [48, 58-61]. Moreover, some $V$. vinifera L. cultivars such as Pinot Noir, red "Chardonnay" and pink "Sultana" produced only nonacylated anthocyanidin-3-O-monoglucosides and M. rotundifolia (Michx.) Small. accumulates only nonacylated anthocyanidin-3,5-O-diglucosides [48, 58, 62-64]. It was demonstrated that the lack of anthocyanidin-3,5-O-diglucosides in $V$. vinifera $\mathrm{L}$. varieties is due to occurrence of double mutation in their anthocyanin 5-O-glucosyltransferase gene [65]. However, hybrid varieties always produce mixtures of anthocyanidin-3-O-monoglucosides and anthocyanidin-3,5-O-diglucosides which is used to monitor their usage in winemaking $[48,57]$. The aglycones of common anhocyanins found in grapes are malvidin 6 , delphinidin 3 , petunidin 5 , cyanidin 2 , peonidin 4 and pelargonidin 1. Malvidin 6 is the predominant anthocyanidin in most of the $V$. vinifera L. varieties (with exception of some "Muscat" cultivars in which cyanidin 2 is the major aglycone), whereas pelargonidin-3-O-glucoside was detected only in trace amounts [48, 66]. Recently trace amounts of pelargonidin-3-O-glucoside and pelargonidin-3,5-O-diglucoside were found to present also in Vitis labrusca L. and Vitis amurensis Rupr., respectively [57, 67]. The absence of pelargonidin 1 derivates in detectable concentrations in grape could be explained with the higher activities of $\mathrm{F}^{\prime} \mathrm{H}$ and $\mathrm{F}^{\prime}{ }^{\prime} 5^{\prime} \mathrm{H}$ in Vitis species, which redirects the metabolite flux to production of cyanidin 2 and delphinidin 3 instead of pelargonidin 1 [48].

\subsection{Anthocyanins relevant to berry quality}

During their growth, grape berries follow a double sigmoid curve [68]. Veraison is the unique stage of berry development, representing the transition from growth stage to ripening. Once the grape berries enter to veraison, many physiological and biochemical changes occur. The grape cells completely redirect their metabolism to production of secondary metabolites, necessary to prepare berries for reaching the stage of physiological maturity. During this stage, the chlorophyll in berries has been completely lost and the biosynthesis of flavonoids, including anthocyanins is promoted [68]. Microarray analysis showed remarkable overexpression of genes involved in flavonoid biosynthesis and particularly in anthocyanin produc- 
tion during veraison and ripening in vinifera, rotundifolia and aestivalis species [47, 69, 70]. With the progress of anthocyanins accumulation the color of grape berries changes from green through red and then to purple due to the subsequent methylation of produced anthoyanins. This results in the increment of the relative shear of more metabolically evolved anthocyanins in the mature berries $[68,71]$. Anthocyanin composition of grape variety is of great importance for estimation of technological properties of berries in winemaking. Thus the varieties, which accumulates predominantly anthocyanins build on anthocyanidins having ortho-positioned hydroxyl groups (cyanidin 2, delphinidin 3 and petunidin 5) are sources of more unstable color, compared to varieties, which accumulates anthocyanins based on malvidin 6, peonidin 4 and pelargonidin 1 [48, 63]. Moreover, the increased amount of acylated anthocyanins significantly contributes to the stabilities of their color $[63,72,73]$. The quantity and quality of anthocyanins plays a crucial role in evaluation of berry qualities and determination of the right time for their collection. To monitor accumulation of pigments in situ, a rapid and non-invasive method based on application of fluorescence sensor has been developed [74, 75]. The method allows anthocyanin content in grape bunches to be monitored non-destructively on the vine in the field and was found to be effective in detecting the earlier ripening processes [74, 75].

\section{Transcriptional regulation of anthocyanin biosynthesis in grapes}

Anthocyanin biosynthesis in grapes commences only when ripening of the berry begins (termed véraison) and normally continues throughout the ripening phase of growth. Anthocyanin biosynthesis pathway in grapes has been greatly investigated, including intracellular transportation and accumulation [18, 76-78]. Most of the structural genes have been isolated, cloned and characterized, and there is valuable information available on the mechanisms that regulate their expression within the plant cell [29, 44, 79]. Multiple regulatory genes under the complex regulation are responsible for the synthesis of anthocyanin at the transcriptional level $[17,18,80]$. The early biosynthetic genes (EBGs), which are upstream of the anthocyanin biosynthetic pathway, are regulated by several different families of genes called the Myb transcriptional factors, Myc transcriptional factors (encoding basic helix-loop-helix proteins, bHLH) and WD40-like proteins [40-42, 81]. On the other hand, late biosynthetic genes (LBGs), which are downstream leading to anthocyanin formation through glycosylation and subsequent modification (methylation and acylation) are under the specific control of several regulatory factors. Specific regulatory genes have been identified and characterized in $A$. thaliana and they include PAP1 \& PAP2 (Myb family), GL3 \& EGL3 (Myc family) and TTG1 (WD40 family). These genes are known to regulate the expression of the structural genes involved in the anthocyanin biosynthesis [82-84]. According to [85], some genes belonging to the Myb and Myc factors (e.g MYBL2, MYB4 and BHLH32) also act negatively to regulate biosynthetic pathway of anthocyanins in A. thaliana. However, in grapes, R2R3-Myb transcriptional factors have been implicated to control different branches of the phenylpropanoid pathway including anthocyanins, flavonols, and proanthocyanidins. Deluc et al. [86, 87], reported that transcriptional factors, Vvmyb5a and Vvmyb5b belongs to this group. However, 
still little is known about the transcriptional regulation of the structural genes involved in anthocyanin biosynthesis throughout berry development.

Recent studies in grapevine indicates that VvMYBA1 and VvMYBA2 transcription factors regulate UFGT gene, which plays a crucial role in the synthesis and accumulation of anthocyanins [56, 88-90], also identified another key R2R3-MYB protein that regulates proanthocyanidins (PA) synthesis in berry skin and seeds. But it is important to note that regulatory genes that control the expression of genes that encodes enzymes located upstream of UFGT have not been identified. It has been suggested that there is a contribution of at least two distinct regulatory complexes involved in the early and late steps of berry development [61]. Another study [86] also revealed that a MYB gene named $V v M Y B 5 a$ is associated with the regulation of the flavonoid pathway during the early phase of berry development. The study of transcription factors involved in the later steps of berry ripening is crucial, so that the coordinate regulatory mechanisms of the biosynthetic pathway throughout the berry development can be understood. R2R3-Myb related transcriptional factors such as VlmybA1-1, VlmybA1-2 and $V l m y b A 2$ have been identified as specifically regulating anthocyanin accumulation. Kobayashi et al. [56] and This et al. [54] revealed that, a retrotransposon, Gret1, is inserted in the 5'-flanking region of its related non-functional VvmybA1 gene, and this contributes to the function lose of its transcriptional factor in white $V$. vinifera L. grapes. However, their research indicated that, the Gret1 insertion is missing from the VvmybA1 genes in red skinned spots of white cultivars, leaving behind a solo long terminal repeat (LTR), which becomes the functional regulatory gene. This means that red and white spots seen in the skins of grape berries are the result of deletion of the inception region of the retrotransposon, Gret1 [91]. VvmybA1 factor is regarded to be the major gene determining the synthesis of anthocyanin in the grape skin, thus the red and white color of the berries [55, 92]. In addition, VvmybA1 and VvmybA2 genes have also been reported to belong to the $V v m y b A$ family regulator genes in grapes, and they are also responsible for the color accumulation of the grape berries [91].

\section{Muscadine grape cells as model system}

Muscadines (Muscadinia rotundifolia (Michx.) Small.) are native grapes of North America and they are considered the most important cultivated grapevine species in the Southeastern part of the United States. Muscadine grapes are well known for their characteristic flavor and popularity in making juices, jellies, jams, and wine. It is important to note that muscadines are the only grapes that contain ellagic acid, which is known for its anticarcinogenic activity. In recent years, their production has increased significantly because of health promoting effects. They are known to have thick, tough skins that result in relatively low yield in juice, and therefore, $40 \%$ to $50 \%$ of the berry skins, pulp and seeds have not been traditionally used. The utilization of muscadine cell lines could have an important economic influence on the muscadine industry by expanding the uses of muscadine beyond the traditional jellies, jams, juices, and wines. Our laboratory (Viticulture lab at Florida A\&M University) has started to investigate the feasibility of using in vitro red cell cultures [93] to improve human health. These cells were established from super-epidermal cells of muscadinia 'Noble' var [93]. They have been 
cultivated from a hard calli to fine cells both in suspension and in solid media. Current functional genomic studies suggest that there is an elevated expression of anthocyanin biosynthetic pathway genes in the in vitro red cells of muscadine [69,94]. Other studies are also underway to evaluate their phenolic compounds and transcriptomics. However, it is important to note that gene expression studies of flavonoid biosynthetic genes are crucial for anthocyanin biosynthesis in the red cells of muscadine.

\subsection{Genetic modification: A promising strategy to up-regulate or down-regulate the production of anthocyanins in muscadine grape cells}

Genetic engineering of plants has lots of benefit in the agricultural field [95-97]. It contributes to an efficient and cost-effective way to produce a wide array of novel, valueadded plant and food products in an environmentally friendly manner. Most scientists including Butelli et al. [98] have highlighted the interest of producing crop plants and their products enriched with health-promoting natural compounds. These compounds include anthocyanins and flavonoids, which have become the targets for improving the nutritional value of foods. This requires an in depth knowledge of the molecular mechanisms underlying the biosynthetic pathways of secondary metabolites in plants as demonstrated by [98]. Even though there are some plants that contain high levels of anthocyanins such as blueberries, there are some species where the accumulation of secondary metabolites is not enough. This is why genetic engineering has been used as a strategy to modify flavonoid biosynthesis in order to enhance flower pigmentation in ornamentals and fruit plants [99-103]. Genetic engineering has become increasingly important worldwide because it provides significant improvements in the quantity, quality, and acceptability of the world's food supply and may be the best source for food security $[5,104]$. Currently there is an increased production of plant-based products with an enhanced antioxidant capacity, which is facilitated by this technology [103]. An example of this approach is in tomato, which is also an important vegetable crop worldwide [98, 105, 106]. Several transgenic approaches have been used to enhance the accumulation of flavonoid levels in grape berries and tomato fruit by overexpressing either the structural or regulatory genes involved in the biosynthetic pathway [87, 107]. Most of these studies have been carried out in vivo, however, none of these have been exploited in the cell models. Although a significant increase in the final content of some flavonoids (flavonols in particular) has been achieved [108-111], the production of anthocyanins in cell cultures still needs to be exploited. Commercial application of grape cell cultures for production of anthocyanin-based colorants is being delayed due to the following main problems: 1.) biosynthetic instabilities of grape cell suspensions; 2.) yield and productivity are too low to justify commercial production economically; 2.) the capacity of cultured cells for anthocyanin accumulation is limited; 3.) anthocyanins are exclusively intracellular and the development of two-phase process based on their continuous secretion and recovery from the medium is difficult; 4.) anthocyanins with desirable application properties may not be achieved using conventional cell line selection and process manipulation. Majority of these problems can be overcome using genetic engineering strategies by focusing on the functional genomics, transcriptomics, and proteomic studies. This will give us the 
ability to select a fast growing cell lines with the ability to produce high yield of target anthocyanin types. Some of the most effective genetic engineering approaches for manipulation of flavonoid biosynthesis pathway in grape cell suspension are discussed bellow by presenting our experience with Native American muscadine grape cells.

\subsection{Modification of the anthocyanin pathway using regulatory genes}

The final assembly of secondary metabolites in plants is determined by the coordinate transcriptional control of structural biosynthetic genes. Based on the information provided in [112], modulation of the rate of initiation of mRNA synthesis depends on the specific transcription factors, which interact with promoter regions of targeted genes. The regulatory genes that control the pattern and intensity of anthocyanin pigmentations through regulating the expression of several flavonoid-anthocyanin structural genes have been identified in many plants [16, 113-115]. There are two families of transcription factors i.e MYB and MYC that are involved in tissue-specific regulation of the structural genes found in the anthocyanin biosynthesis [14, 116-118]. It is notable that these transcription factors have a sequence homology from different plant species that shows that they have a common ancestor. In our previous study, an ectopic expression of the $M Y B$ gene in embryonic cell lines of muscadine grapes confirmed that these regulatory genes can be used for genetic modification of cell cultures in order to increase the final anthocyanin accumulation in cells [119]. However, it is vital to note that the quantity and class of anthocyanin produced might depend on several factors including 1.) How the transcription factor binds to the specific promoter site of the targeted structural gene, 2.) The ability of the endogenous transcription factors to cooperate with the introduced regulators, and 3.) How functional the endogenous transcription factors are $[8,116]$. It is important to note that the enhancement of anthocyanin production using genetic engineering was achieved more than a decade a go in model plants such as Arabidopsis, tobacco, maize, and tomato [109, 120]. In Arabidopsis and tobacco, this was done by introducing the maize regulatory genes $\mathrm{R}$ and $\mathrm{C} 1$ [121]. The over-expression of the regulatory gene $\mathrm{R}$ by itself was able to trigger anthocyanin accumulation in the tissues that originally did not produce anthocyanin in Arabidopsis and tobacco [121, 122]. But, when the C1 gene was expressed by itself, there was no pigmentation. In another study carried out by Lloyd et al. [121], the over-expression of CI and LC gene in Arabidopsis triggered the accumulation of anthocyanins in tissues that normally do not contain them. The same applies to transgenic cherry tomatoes that showed the accumulation of anthocyanins in the leaves, stems, sepals, and veins, when LC gene was over-expressed [122]. Recently, Deluc et al. [87], isolated $V v M Y B 5 b$, a transcription factor that encodes a protein that belongs to the R2R3-MYB family of transcription factors in $V$. vinifera $L$. This protein displays significant similarities with $V v M Y B 5 a$, another MYB factor that has been shown to regulate flavonoid synthesis in grapevine [86]. Transient expression of the cDNAs for VvMYB5a and VvMYB5b in grape cells confirmed that they can activate the grapevine promoters of several structural genes of the flavonoid pathway [87]. Deluc et al. [87], also determined that the over-expression of VvMYB5b gene in tobacco lead to an up-regulation of genes encoding enzymes of the flavonoid pathway and also triggered the accumulation of anthocyanin and proanthocyanidin compounds. 
In addition to the over-expression of the transcription factors, the suppression or negative regulators of flavonoid biosynthesis have been described [123]. For instance, high pigmented phenotypes (hp-2) in tomato were revealed when Bino et al. [123], mutated the DE-ETIOLATED1 gene (DET1). The fruits produced from these mutants are dark, and it is because of the elevated levels of flavonoids and carotenoids. The suppression of the regulatory gene Det-1 resulted in increased levels of secondary metabolite groups. Further study of the mutants by Davuluri et al. [124], indicated that flavonoid levels were increased up to 3.5 fold, lycopene content was two-fold higher and $b$-carotene levels accumulated up to ten-fold compared to wild type fruits. This is an indication that we can use both over-expression and suppression (RNAi) techniques to improve anthocyanin production in grape cells.

\subsection{Modification of the anthocyanin pathway using structural genes}

The regulatory gene families MYB and MYC control the structural genes within the grape anthocyanin biosynthetic pathway $[87,107]$. But it is important to note that, the way in which the structural genes are regulated in grape berry skins appears to be different from the patterns observed in snapdragon, petunia, and maize [125-127]. There are two ways in which the pattern of gene expression in grape berry skins could be explained in relation to regulatory genes; 1.$)$ early biosynthetic genes, which induces the expression of all of the structural genes except UFGT, and 2.) late biosynthetic genes that results in the induction of expression of all structural genes [1]. Alternatively, two types of regulatory genes may be present, one that controls expression of PAL, CHS, CHI, F3H, DFR and LDOX and another that induces UFGT gene expression [43]. This means that the regulatory gene that controls expression of PAL, CHS, CHI, F3H, DFR, and LDOX is expressed early in berry development. But it is crucial to note that many studies have identified UFGT, as the major control point to anthocyanin biosynthesis in grape berry skins, and this control is later in the pathway than has been observed in the studies of maize, petunia, and snapdragon anthocyanin biosynthesis.

Irrespective of the function of the regulatory genes, ectopic expression of the structural genes can also enhance the accumulation of anthocyanins. A study carried out by Muir et al. [108] determined that an ectopic expression of the Petunia $\mathrm{CHI}$ gene in tomato fruits increased total flavonoids up to 70-fold in tomato fruit peel. Particular flavonoids increased consisted mainly of the flavonols rutin (quercetin 3-rutinoside) and isoquercetin (quercetin-3-glucoside), and to a smaller but still substantial extent of kaempferol glycosides. In another separate study, Colliver et al. [128] increased the amount of flavonoids in the flesh of tomato fruit by introducing a four-gene construct that lead to concomitant ectopic expression of structural genes, CHS, CHI, F3H and FLS in tomato fruit. This resulted in increased levels of flavonols in both peel (primarily quercetin glycosides) and flesh (primarily kaempferol glycosides) [128]. When expressed separately, none of these four genes was sufficient to lead to flavonol production in fruit flesh. This kind of approach can be replicated in grape cell cultures, by concomitantly over-expressing structural genes such as DFR and LDOX to enhance the accumulation of anthocyanins. These studies indicate that transgenic approaches can be taken to increase anthocyanin production levels in muscadine grape cell cultures by overexpressing either the structural or regulatory genes involved in the biosynthetic pathway. 


\subsection{Blocking specific steps in the anthocyanin biosynthetic pathway using RNAi: control of the flavonoid flux}

Silencing the structural or regulatory genes on the anthocyanin pathway in muscadine requires the following steps: 1) isolation of the endogenous structural or regulatory gene; 2) construction of the transformation cassettes using structural or regulatory-gene fragments as transgenes; 3 ) transformation of transgenic red cells via Agrobacterium tumefaciens and regeneration; 4) molecular analyses to identify transgenic muscadine cell lines; 5) Protein analyses of transgenic cells to confirm the suppression of flavonoid-related proteins.

The flow of genetic information dictates that "DNA is transcribed into RNA that is translated into a protein" (Fig 7A). Flavonoid biosynthetic proteins are produced using this concept. To shift the metabolic flux in muscadine grape cells, one can consider either 1) over-expressing the genes on the flavonoid pathway or 2) to knock out the production of the flavonoid proteins. Blocking the production of flavonoid proteins can be done by interfering with the flow of the genetic information. For example, to eliminate the production of the muscadine DFR protein (Fig 7B), we could interfere either at the mRNA transcription level (transcriptional gene silencing [TGS]) or at the post-transcriptional level (PTGS). The advancements made in genetic engineering have led to the possibility of knocking out the production of specific proteins in organisms by downregulating and/or silencing the genes encoding these proteins. Strategies developed to downregulate genes in plants include mutation-based reverse genetics [129], gene targeting [130], antisense RNA [131], cosuppression [95, 132], and RNA interference (RNAi) [133]. Genetic and biochemical evidences suggest that antisense-mediated gene silencing, co-suppression, and RNAi are all inputs into a common RNA silencing pathway triggered by the formation of a double-stranded RNA (dsRNA). This pathway, called PTGS, is characterized by accumulation of 21 to 25 nucleotides, small-interfering RNAs (siRNAs), sequence-specific degradation of target mRNA, and methylation of target gene sequences [134]. A typical example is demonstrated by Muir et al. [108], where they used RNAi to blocked specific metabolic conversions in the endogenous tomato flavonoid biosynthesis pathway by down-regulating the expression of specific structural flavonoid genes. In another study, Schijlen [135] also used RNAi technique to inhibit tomato CHS1 gene and this resulted in a strong reduction of total flavonoid levels (naringenin chalcone and quercetin rutinoside). Based on these data, they decided to use an RNAi-mediated gene construct to block the flavonoid pathway leading to flavonols at CHS, F3H and FLS [103]. In all these studies, a clear reduction of flavonols was obtained by introducing an RNAi construct. But it is important to note that when the FLS RNAi-construct was introduced, there was high accumulation of anthocyanins in the vegetative tissues such as stems, leaves, and flower buds as a result of the decreased activity of FLS. Therefore, based on these studies, it is possible that dihydroflavonols as the natural substrates for both FLS and DFR were efficiently converted into anthocyanins [103]. This is because the decrease of FLS activity may have caused less competition between the flavonol and anthocyanin branches in vegetative tissue of FLS RNAi-tomatoes, thereby improving the metabolic flux towards anthocyanin end products. This is a demonstration that RNAi technique can be used to re-direct the metabolic flax in cell cultures to produce more anthocyanins or flavonoids based on the consumer's interest. 


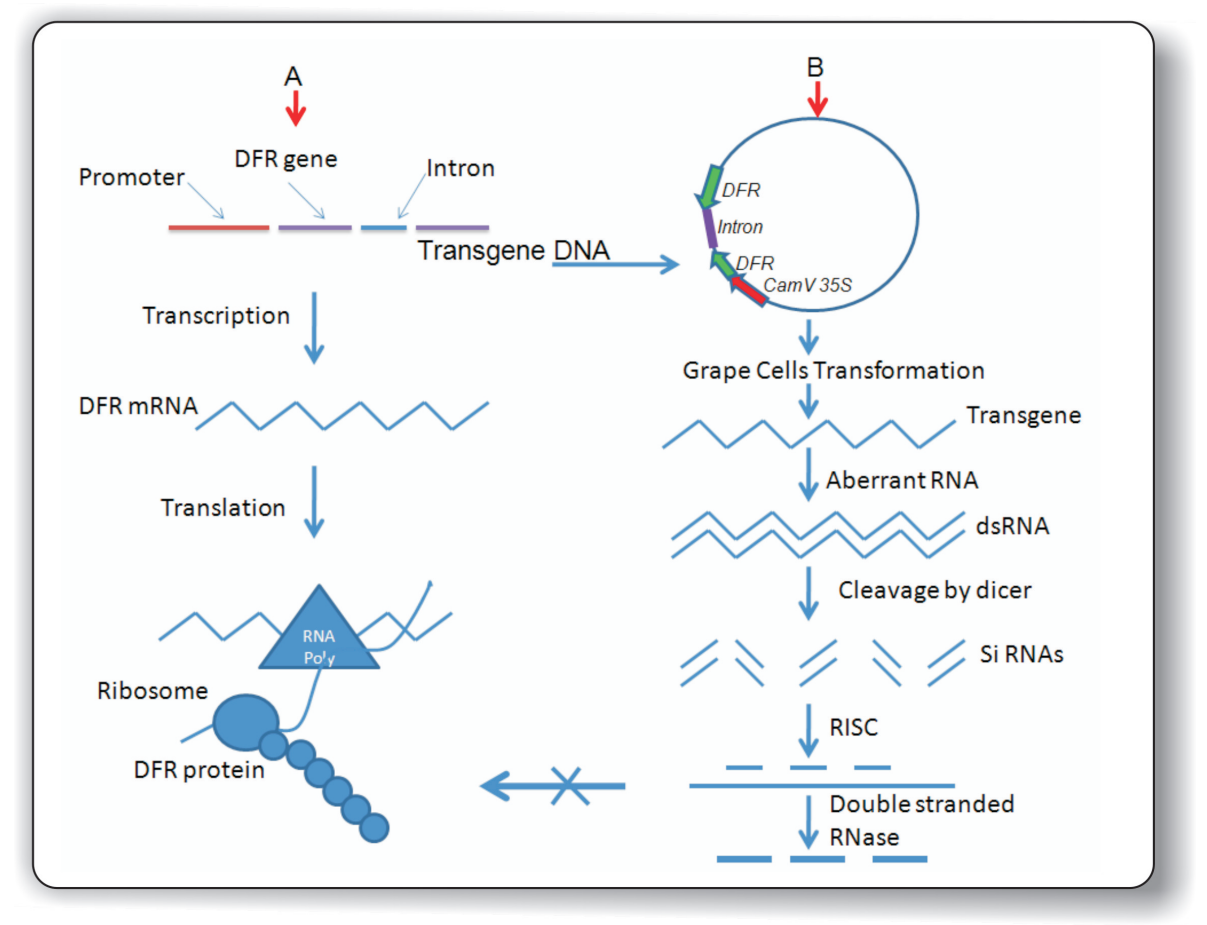

Figure 7. Schematic representation describing the flow of genetic information. A, The Central Dogma of Molecular Biology: $d f r$ gene is transcribed into a messenger RNA, which is translated into a DFR protein. B, Schematic representation highlighting key steps in silencing structural or regulatory genes based on the RNAi model using DFR as an example. dsRNA-double-stranded RNA; RNAi-RNA inteference; RISC-RNA-interfering silencing complex; RNaseribonuclease. Post-transcriptional gene silencing is initiated by dsRNA molecules that mediate the degradation of homologous transcripts. B gives a schematic representation of the molecular process that would be involved in the degradation of mRNA transcripts from muscadine DFR genes, based on the PTGS model. A fragment of the DFR gene is amplified by polymerase chain reaction (PCR) and cloned into a transformation vector. This vector is a DNA vehicle, which transfers the DFR gene fragment (called transgene) into muscadine grape cells following Agrobacterium-mediated transformation. The transgene integrates into the endogenous DNA of muscadine cells for expression. Transcripts from the transgene initiate long dsRNA molecules, which would be processed into small 21 to 25 nucleotides (siRNAs) by an endogenous RNAIll enzyme called "Dicer" [136]. These siRNAs would guide the RNA-interfering silencing complex (RISC), which contains the proteins necessary for unwinding the double-stranded siRNAs, and cleave the endogeneous DFR mRNAs at the site where the antisense RNAs are bound [137]. Sources of dsRNA formation from DFR transgene transcripts include: 1) pairing of transcripts transcribed from an inverted repeat (IR) transgene; 2) pairing of the normal sense RNAs and antisense RNAs (asRNA) arising from aberrant transcription of the transgene; 3 ) pairing of complementary regions of RNA degradation products; and 4) pairing of transcripts with antisense RNA (asRNA) produced by RNAdirected RNA polymerase (RdRP) [138, 139].

\section{Key concepts for enhancing anthocyanin biosynthesis in grape cell lines}

Grape cell suspension cultures have been extensively studied as an model for elucidation of anthocyanin biosynthesis pathway, for performing functional genetic studies, somatic embryo 
development and most importantly as an alternative source of natural colorants [1, 69, 140-142]. Cultivation of plant cells in controlled conditions offers advantages of continuous supply of high quality anthocyanin pigments. However, scientists have tried for over 40 years to produce anthocyanins in different cell systems, but until now, no commercially feasible anthocyanin producing system has been developed. Switching the production of natural pigments from the traditional approach (involving implementation of numerous agricultural activities) to modern industrial biotech factories is not an easy task. But it is obvious that for the successful realization of such biotechnological advances, research on both empirical and rational levels have to be performed [143]. To succeed in such challenges, we propose to follow a simple integrated approach based on consecutive conduction of various multidisciplinary experiments, optimization and monitoring procedures (Figure 8). As we already discussed some of the rational approaches for manipulation of anthocyanin biosynthesis on genetic level, in the next few pages, the basic principles of empirical studies are highlighted and the current progress on them has been reviewed.

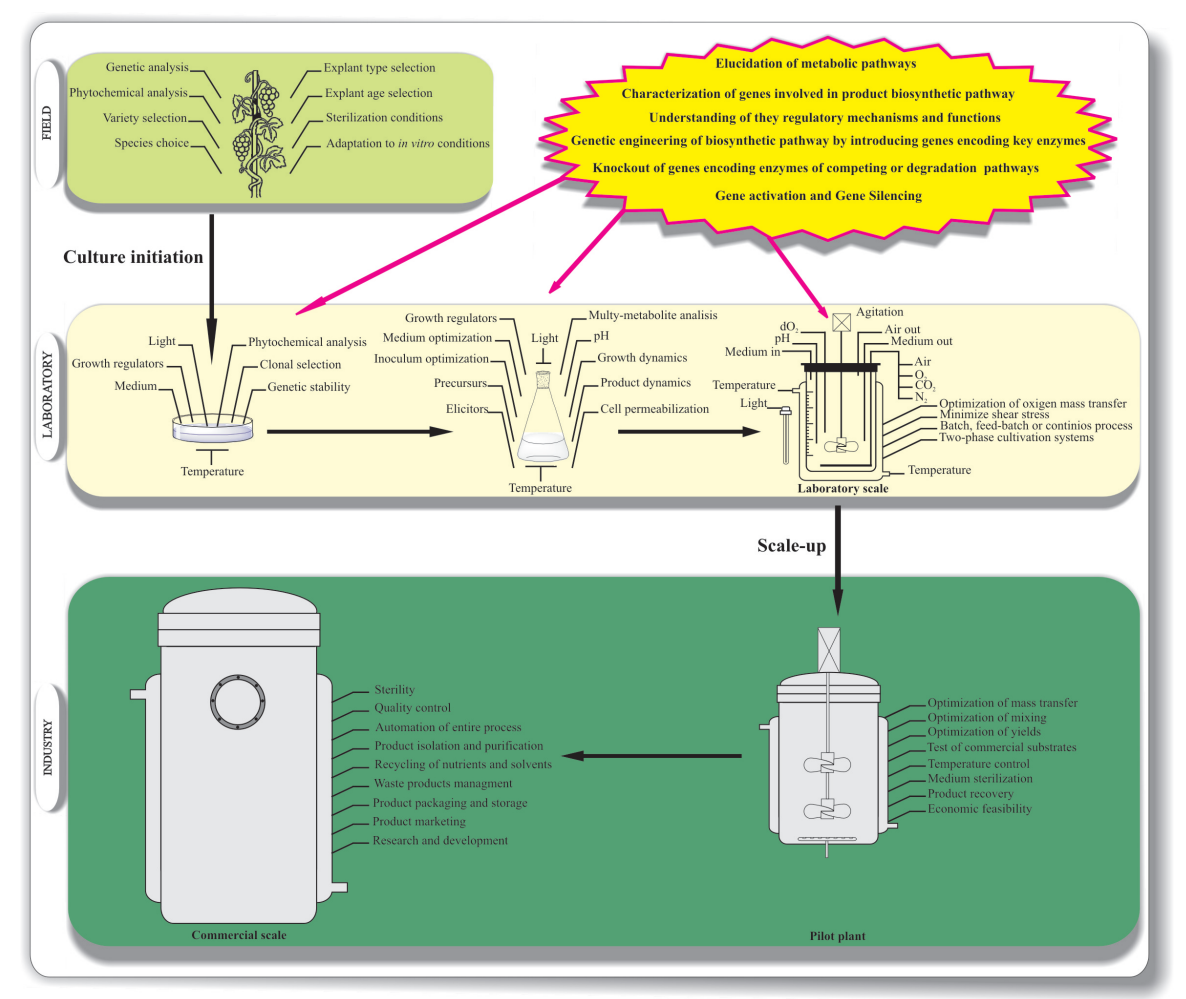

Figure 8. Basic concepts for the development of biotechnological system for anthocyanins production based on grape cell suspension culture. The key steps in bioprocess engineering and optimization of anthocyanins production, involving application of both empirical and rational approaches are presented on each technological stage. 


\subsection{Cell line development and improvement}

The first step for creation of biotechnology process for anthocyanins production is the development and selection of high producing cell line. To facilitate this process several important preliminary questions needs to be answered. The most important is the right choice of plant species (respectively, the appropriate cultivar) having the necessary anthocyanins profile in both quantity and quality aspects. Recently Lazar and Petolescu [144], generated cell suspension cultures of six grapevine varieties (Burgund Mare, Cabernet Sauvignon, Merlot, Oporto, Negru Tinctorial and Pinot Noir). They cultivated them in a laboratory bioreactor and demonstrated that the growth rates and biosynthetic potential for anthocyanins production were in strong dependence of cultivar used for culture initiation [144]. Currently, most of the research on grape cell suspensions have been performed with cell lines derived from two sources - V. vinifera L. cv. Gamay Fréaux and Vitis hybrid Bailey Alicant A (V. lincocumii $x$ V. labrusca $x$ V. vinifera $) \times(V$. vinifera $x V$. vinifera $)[1,48]$. Both of them are teinturier cultivars which usually produce malvidin-derivatives in berry skin and peonidin-derivatives in the pulp [145]. Cell suspension cultures of $V$. vinifera L. cv. Cabernet Sauvignon (CS4 and CS6) were also reported [146]. In our laboratory we have patented anthocyanin producing cell suspension cultures of Muscadinia spp. and V.aestivalis var. Cynthiana, which produces mainly anthocyanidin-3,5-O-diglucosides [93].

After the choice of targeted variety, the critical step is the selection of appropriate explants, which are used for callus initiation. The type and the age of explants, as well as the environmental conditions at which they are collected are critical factors for successful initiation of in vitro cultures [147]. Sterilization procedure, applied to the explants should be as gentle as possible and the necrotic ends of the sterilized cuttings must be removed to avoid the secretion of phenolic compounds into the induction medium. In some cases, the addition of activated charcoal or antioxidant mixture into the culture medium is necessary [147]. Two-phase cultivation systems with adsorbent resin like Amberlite XAD4, which have been recently applied in shoot regeneration and hairy root induction, could be also a prospective alternative for reducing explants browning $[148,149]$. One of the most typical characteristic of grapevine callus cultures is their high heterogeneity concerning coloration. The obtained calli usually exist as a mixture of colorless, yellow and red clusters $[1,142,150]$. Therefore, the repeated selection and subcultivation of different-colored clusters can be applied for screening of new high producing lines [142, $146,150,151]$. As a result of such selection procedure, significant changes in anthocyanin profiles of isolated lines could be observed $[142,146]$. Usually those changes lead to the elevation of the $3^{\prime}$-methylated and acylated anthocyanins in grape cell suspension cultures and therefore greatly improve the quality of overall pigments with regards to their color stability [72, 142, 152]. As an example, in cell suspension of $V$. vinifera L. cv. Gamay Fréaux, the major anthocyanins were found to be cyanidin-3-O-glucoside 7, peonidin-3-O-glucoside and cyanidin-3-O-pcoumarylglucoside 9 [153]. By repeated selection of colored aggregates from the same culture, Krisa and colleagues obtained a line, which produce remarkably high level of malvidin-3-Oglucoside (63\% of total anthocyanin content) [146]. However, in analog with callus culture, the grape cell suspensions usually consist of a mixture of uncolored cells and red colored anthocyanin producing cells [51, 142, 150,151]. Moreover, the colorless cell fraction often has a high growth rate compared to the red fraction and this is the main factor that contributes to instabili- 
ty of the supensions as regards anthocyanin production [150,154]. With time, anthocyanin producing grape cell suspensions could significantly decrease their ability to produce anthocyanins and often the yields, obtained by the cultivation at equal conditions in the same cultivation vessels are unpredictable [142]. The other complication is due to the existence of strong correlation between cell differentiation, anthocyanin accumulation and cell growth [1]. Anthocyanins are produced only in cells that undergo some level of differentiation (growing as small aggregates), whereas the fast growing, undifferentiated fraction of cells (growing as single cells) does not produce the pigments $[1,155]$. It was found that the fraction of aggregates larger than $0.6 \mathrm{~mm}$ accumulates high amounts of anthocyanins, whereas with the reduction of aggregate size to $0.2 \mathrm{~mm}$ the concentration of produced anthocyanins decreases with $50 \%$ [155]. To control the ratios between non-pigmented and pigmented cells, as well as between aggregated and single cells, the period of sub-culturing and the size and age of used inoculums should be precisely adjusted $[1,150]$. Optimization of the parameters for the inoculums has often been underestimated by researchers, working with plant cells. However, the establishment of right parameters for the inoculum has been found to have significant impact on growth and secondary metabolite production by different plant cell suspensions and hairy root cultures $[3,7,156,157]$. The size of inoculum could significantly shorten the lag phase of grape cell suspension, as well as to affect the culture response to different changes in nutrient composition [158]. In our laboratory, we investigated the effect of different inoculum sizes on growth of anthocyanin producing M. rotundifolia var. "Noble" cell suspension cultures (Figure 9). The experiment was performed in submerged flasks by using 9, 15, 20 and $30 \%(\mathrm{v} / \mathrm{v})$ inoculum of 14 days old cell suspension. The maximum amount of accumulated fresh biomass $(78.7 \pm 1.7 \mathrm{~g}$ FW/L) was achieved when 20 $\%$ of the inoculum was used. At these conditions, the amount of accumulated fresh biomass was 3.18-fold higher, compared to the experiment at which $9 \%$ of the inoculum was used, without observing any decrease in anthocyanin production (unpublished data).

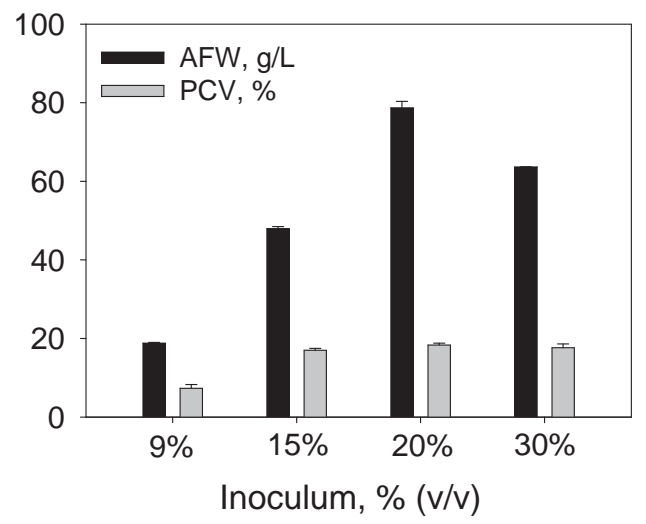

Figure 9. Effects of the inoculum sizes (14 days old culture) on accumulated fresh weight (AFW) and packed cell volume (PCV) by M. rotundifolia var. "Noble" cell suspension culture cultivated in shaking flasks $(250 \mathrm{ml} / 50 \mathrm{~mL})$ for 18 days. The presented values are means with standard deviations of two independent experiments repeated twice $(n=4)$. 
However, the non-homogenous growth of grape cell suspensions could be a serious issue for large-scale cultivation of these in vitro cultures because of the complicated mass transfer in bioreactor systems. It has been observed that grape callus culture can undergo dramatic changes in their anthocyanin profiles, because of their high heterogeneity and somaclonal variability. To prevent those negative effects, a periodical implementation of deep phytochemical, genetic and metabolomic analyses are requires. This will retain acceptably high biosynthetic potential in selected lines during their maintenance.

\subsection{Medium optimization}

The optimal balance of nutrients in cultivation medium has been found to be an essential factor, determining the success on in vitro cultivation of plant cells and tissues. Plant cell suspensions are exceptionally sensitive to concentration of macronutrients, microelements, growth regulators, nitrogen and carbon sources. Even insignificant changes in composition of cultivation medium could promote the appearance of significant changes in cell morphology, growth and secondary metabolite profiles. For example, transferring of anthocyanin producing cell suspension of M. rotundifolia var. "Noble" from the original B5 medium into LS medium completely change the color pattern from red to yellow and the cell growth pattern from small colored aggregates to single colorless cells (Figure 10) (unpublished data).

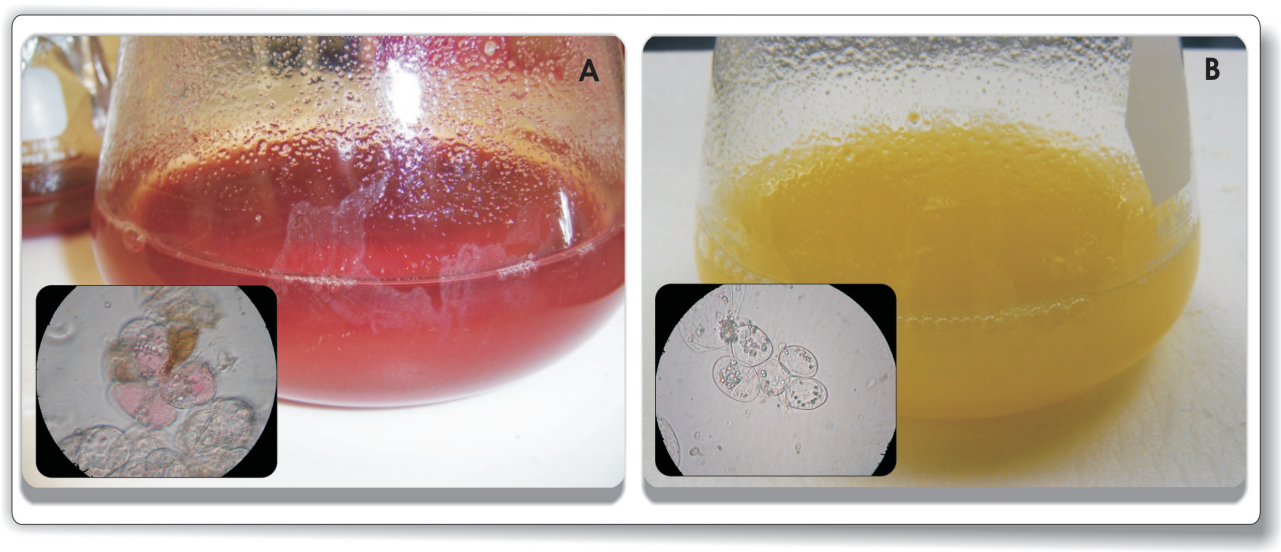

Figure 10. Cell suspension of $M$. rotundifolia var. "Noble" cultivated in shaking flasks on: A - B5 medium; B - LS medium.

As the grape cell suspensions exist as mixture of colored and colorless cells, the optimal cultivation medium should be developed by the way to provide a right balance between the growth rates of both cell populations [1, 142]. Finding the right nutrients balance is often a complicated task mainly because of the observation that the colorless population usually has better growth characteristics and the colored cells showed slow growth [1, 142, 150]. Dedaldechamp and Uhel [154] isolated a cell line from colorless cells of $V$. vinifera L. cv. Gamay Fréaux and demonstrated that under reduction of cell division by phosphate de- 
ficiency, the anthocyanin production was reactivated in colorless cells [154]. Removing of phosphate ions from the medium leads to significant decrease of cell growth but remarkably increase anthocyanin production due to the increasing transcript levels of UFGT and $V v m y b A 1$ genes [159]. Reduction of nitrate ions in the cultivation medium to a critical level was also found to enhance the anthocyanin production in cell suspension of Vitis hybrid Bailey Alicant A [160]. Increased osmotic pressure in medium, caused either by the increased sugar concentrations or by the addition of osmotic-active compounds as D-manitol, sorbitol, poliol or carboxymethyl cellulose has been found to play a critical role for anthocyanin production by different grape cell suspension cultures [155, 160-163]. Because of the significant differences in nutrient media compositions required to provide optimal cell growth and that to activate anthocyanin production, most of the authors used two-stage cultivation involving usage of "maintenance" medium, following by next transfer on "production" medium $[1,142,146,150,160]$. The maintenance medium provides rapid growth of the grape cell culture but the lines often lost their colors. When transferred on production medium, the growth was usually almost completely inhibited, but the anthocyanin accumulation was significantly enhanced. The production medium usually differs from the maintenance medium by the increased sugar concentration, decreased phosphate and nitrate concentrations, supplement of osmotic-active compounds, growth regulator compositions etc. [1, 142, 150,146, 160]. However, it is obviously that the commercial realization of such two-stage based cultivation process is accompanied with numerous complications from technological point of view. In fact, this is one of the main reasons for the lack of industrial process for anthocyanins production by grape cell suspensions.

\subsection{Effect of the $\mathrm{pH}$}

Since the $\mathrm{pH}$ is an important factor for anthocyanin stability and activities of enzyme systems in plant cells, its value in the cultivation medium is critically important for the regulation of both pigments and biomass yields. Recently, the effect of $\mathrm{pH}$ in culture medium was investigated on callus cultures of three grapevine varieties (Coarnă neagră, Fetească neagră and Cadarcă) [164]. The authors observed that the largest amount of accumulated anthocyanins $(13.5 \mathrm{mg} / \mathrm{g} \mathrm{FW})$ were registered in callus culture of Fetească neagră, cultivated on the medium with the $\mathrm{pH}=4.5$. When cultivated on medium with $\mathrm{pH}=9.0$, the anthocyanin production by the same culture was significantly decreased (up to $3.2 \mathrm{mg} / \mathrm{g} F W$ ) [164]. Suzuki and colleagues [162], investigated the growth and production of anthocyanin in grape cell suspension from Vitis hybrid Bailey Alicant A cultivated on media with different $\mathrm{pH}(4.5,5.5,7.0$ and 7.5) [162]. The authors found that the best growth and pigment production were recorded when cultivation was done on medium with the $\mathrm{pH}=4.5$. In contrary to that, when cultivated on medium with $\mathrm{pH}=7.0$ the cell growth and the anthocyanin production were almost completely inhibited. Moreover, the percentage of pigmented cells were significantly decreased with the increase of $\mathrm{pH}$ (from $50 \%$ at $\mathrm{pH}=4.5$ to $4 \%$ at $\mathrm{pH}=7.5$ ) [162]. Because the $\mathrm{pH}$ value of culture medium during plant cell cultivation processes correlates with the metabolism of nitrogen sources, it is important to render an account of this factor during creation of experimental matrices for optimization procedures of nutrient medium composition (especially ammonia/nitrate ratio). 


\subsection{Effect of temperature}

Temperature has a strong effect on anthocyanin biosynthetic pathway, since some cold regulation genes are involved on it $[165,166]$. Anthocyanin accumulation in berry skins of "Aki Queen" (V. labrusca $\times$ V. vinifera) after temperature treatment during ripening was significantly higher at $20{ }^{\circ} \mathrm{C}$ compared to that at $30{ }^{\circ} \mathrm{C}$ [167]. Similar effect was reported for berries of $V$. vinifera L. cv. Cabernet Sauvignon, where the anthocyanins concentration was reduced more than $50 \%$ with the increase of cultivation temperature from $25{ }^{\circ} \mathrm{C}$ to $35{ }^{\circ} \mathrm{C}$ [168]. The authors suggest that the observed decrease in anthocyanin concentration under high temperature was as a result of both anthocyanin degradation and inhibition of mRNA transcription of the anthocyanin biosynthetic genes [168]. Recently, a qRT-PCR analysis have been carried out to compare the expression levels of MYB-related transcription factor genes in the berry skins of "Pione" (V. vinifera $\times$ V. labruscana) during temperature and light treatments [169]. The authors demonstrated that both low temperature and light irradiation were needed to induce the expression of V1mybA1-3 (gene, encoding MYB-related transcription factors that regulate anthocyanin biosynthesis pathway genes), whereas the expression of Myb4 (the repressor of UFGT) was up-regulated only by high temperature, independently of the light levels [169]. However, in optimization procedures for anthocyanin production by grape cell suspension cultures, the influence of temperature was underestimated. The new data, discovering the importance of those critical parameters in regulation of anthocyanin biosynthetic pathways outline the necessity for conduction of more experiments concerning optimization of temperature during cultivation of grape cell suspensions.

\subsection{Light}

Light is an important controlling agent in anthocyanin biosynthesis [166]. Light has been found to induce the expression of genes, responsible for activation of the promoters of the flavonoid pathway genes (MybpA1), but it has no effect on expression of repressor of UFGT (Myb4) in grape berries of vine 'Pione' (V. vinifera $\times$ V. labruscana) [169]. Recently it was demonstrated that UV-A light significantly stimulate the expression of structural genes, encoding the entry enzymes of the shikimate pathway, whereas only the UV-B and UV-C irradiation triggers the production of various anthocyanins in grape berries of $V$. vinifera L. cv. Cabernet Sauvignon [170]. Illumination of grape callus and cell suspension cultures is of great importance for expression of their anthocyanin producing potential. In our laboratory, we investigated the influence of light on anthocyanin production in callus culture of M. rotundifolia var. "Noble" (Figure 11). The red colored line was selected by 3 months repeated selection of dark red colored clusters, grown under illumination ( $16 \mathrm{~h}$ light : 8 dark). When the red colored line was transferred for cultivation in darkness, the culture completely lost its color for one subcultivation cycle (31 days). The obtained colorless culture was supported on darkness for 3 more sub-cultivation cycles and then transferred back under illumination ( $16 \mathrm{~h}$ light: 8 dark). Fourteen days after the light treatments began, the culture started to form red colored clusters and the total anthocyanin concentration reached the original levels, detected in initial red colored lines after 31 days of light exposure (unpublished data). 


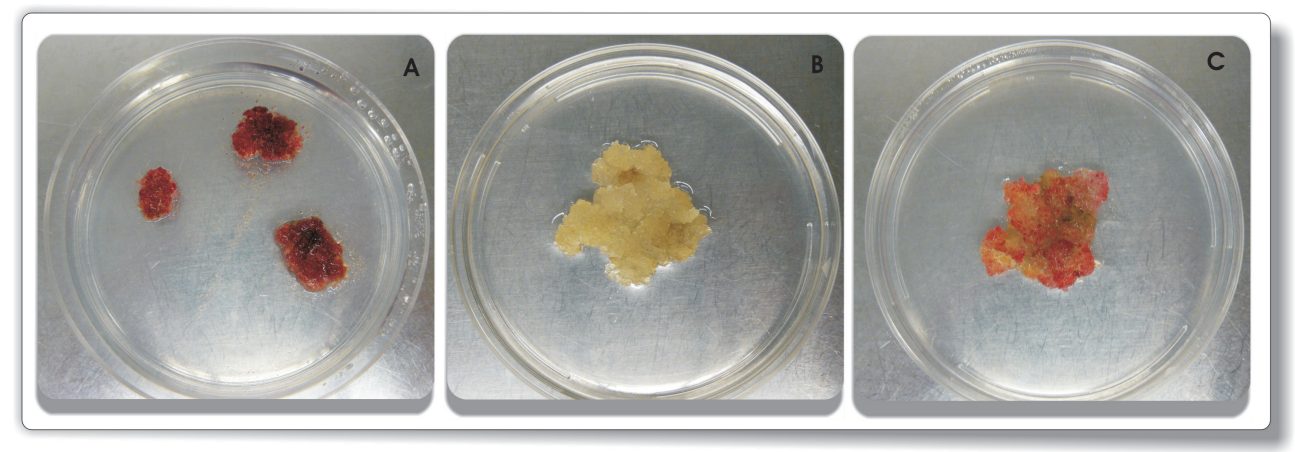

Figure 11. Anthocyanin accumulation in callus culture of $M$. rotundifolia var. "Noble": A - under illumination (16 h light : 8 dark); B - on darkness; C - roll-back under illumination (16 h light : 8 dark) of the culture, cultivated on darkness. The presented pictures are on the 14 days old cultures.

Lazar and colleagues investigated the effect of light on anthocyanin accumulation by callus cultures from six grapevine varieties (Burgund Mare, Cabernet Sauvignon, Merlot, Oporto, Negru Tinctorial and Pinot Noir) [171]. They found that the light has a stimulating effect on anthocyanin production in all calli studied, but the amount of accumulated pigments was in strong correlation with the genotype of variety used for callus initiation [171]. In grape cell suspension of $V$. vinifera L. $c v$. Gamay Fréaux, treatment with light leads to additional increase of peonidin-3-O-glucoside with $0.6 \mathrm{mg} / \mathrm{g}$ DW [172]. The same group reported that the continuous light irradiation (8000-8300 LUX) can contribute up to 4.8 -fold increase in anthocyanin accumulation compared to no illuminated control [173]. Combined treatment with light and elicitor (jasmonic acid) additionally increased anthocyanins production (13.9-fold compared to non-treated control) [173]. It is obvious that the light requirements of grape cell suspension cultures can cause a serious complication during the scale up of cultivation process. Cormier and colleagues reported the isolation of red colored clusters growing on darkness, but the line has been very unstable and easily changed to variegated culture [142]. However the authors succeeded to obtain stable anthocyanin producing cell line in suspension culture but the production of pigments was relatively low $(1.32 \mathrm{mg} / \mathrm{g}$ FW) [142]. Therefore, much effort is needed to initiate light-independent high anthocyanin producing cell lines, which will greatly facilitate the transfer of the process to large-scale bioreactors.

\subsection{Effect of growth regulators}

Availability of growth regulators (auxins and cytokinins) in cultivation medium are essential for ensuring the growth and to determine the levels of produced secondary metabolite by in vitro cultivated plant cells. In the case of anthocyanin biosynthesis in grape cell suspension, the composition of growth regulators in the medium can be of great importance for the production pigments [1]. Hirasuna and colleagues [160], tested the effects of different auxins (IAA, NAA, IBA and 2,4-D) and cytokinins (Kinetin and BAP) on anthocyanin biosynthesis by Vitis hybrid Bailey Alicant A cell suspension, cultivated on specially composed production 
medium [160]. The authors found that the synthetic auxin 2,4-D has stimulating effect on anthocyanin biosynthesis over a wide range of concentrations, whereas the addition of cytokinins even in low concentrations completely inhibit the pigments production. However, the effects of growth regulators are unpredictable and should be evaluated experimentally for every individual cell line. As an example, Krisa and colleagues [146], reported that for cell suspension of $V$. vinifera L. $c v$. Gamay Fréaux, the addition of NAA as auxin leads to better anthocyanin accumulation compared to when 2,4-D was used [146]. Moreover, their suspension culture requires the addition of cytokinin, Kinetin for ensuring the culture growth and production of pigments. The change of Kinetin with BAP results to inhibition of anthocyanin production [146]. Recently, Gagne and colleagues demonstrated that abscisic acid (ABA) promotes anthocyanin production in grape cell culture of $V$. vinifera L. cv. Cabernet Sauvignon (CS6) by the expression of some genes in the upstream part of the flavonoid biosynthesis pathway [174].

\subsection{Effect of elicitors and precursors}

Application of different (biotic or abiotic) elicitors has been proved to be an effective strategy for enhancement of the production of secondary metabolites related to the plant defense system [175]. Anthocyanin biosynthetic pathway as a part of phenylpropanoid metabolism of plant cells could be significantly manipulated by application of different elicitors or feeding with specific precursors. Treatment of cell suspension culture of $V$. vinifera L. cv. Gamay Fréaux with a combination of phenylalanine as a precursor and methyl jasmonate as an elicitor resulted in a 3.4-fold increase in anthocyanin yield compared to the control [151]. Cell suspension culture of $V$. vinifera L. $c v$. Gamay Fréaux was recently used as a model system for evaluating the effects of different chemical (streptomycin, activated charcoal, ethephon, indanoyl-isoleucine and N-linolenoyl-l-glutamine), biotic (insect saliva, chitosan, pectin, alginate, yeast extract and gum arabic) and physical (hydrostatic pressure and pulsed electric field) elicitors on anthocyanin biosynthesis [176-180]. It was found that the combined treatment of samples with pulsed electric field and ethephon, lead to a 2.5-fold increase in anthocyanin content, whereas the combination of hydrostatic pressure and ethephon does not alter anthocyanin production, but increases the other flavonoids [176, 177, 180]. The application of indanoyl-isoleucine enhanced the anthocyanin production with 2.6-fold, whereas the insect saliva stimulated the production of phenolic acids [178]. In contrast to insect saliva, the other investigated biotic elicitors (chitosan, pectin, and alginate) had a significant effect on anthocyanin production (resulted on 2.5-fold, 2.5-fold, and 2.6-fold increase compared to control, respectively) [179]. The most widely used elicitors are methyl jasmonate and jasmonic acids, which seems to have better beneficial effects on accumulation of phenolic acids and stilbenes than the accumulation of anthocyanins [181, 182]. However, jasmonic acid was found to increase preferably the level of peonidin-3-O-glucoside (from 0.3 to $1.7 \mathrm{mg} / \mathrm{g} \mathrm{DW}$ ) and the relative share of acylated anthocyanins (from $32 \%$ to $45 \%$ ) in cell suspension of of $V$. vinifera L. cv. Gamay Fréaux, whereas the concentrations of the other major anthocyanins were insignificantly increased [172]. The effect of jasmonic acid was significantly increased when combined treatment with light irradiation was applied [172]. Magnesium treatment of cell suspension of $V$. vinifera L. cv. Gamay Red was found to increase the anthocyanin concentration 
by inhibiting the degradation of pigments but not by promoting induction of biosyntheticrelated genes [183].

\section{Commercialization and applications of grape cell products}

The increased demand of natural colorants and nutraceuticals determines the needs for development of alternative technologies for supply of such additives. The anthocyanins, produced by grape cell suspensions, represent a very attractive class of natural compounds, which could find application in food industry (as colorants), pharmacy (as nutraceuticals and therapeutic compounds) and in cosmetics (as UV protectors, antioxidant and anti cancer compounds). Biotechnological production of grape anthocyanins presents significant economical benefits. Cormier and colleagues calculated that the cost of $1 \mathrm{~kg}$ anthocyanins, produced by two-stage cultivation process of grape cell suspension in bioreactor with working volume of 155,000 L can cost almost the half of the price of such amount of anthocyanins, produced by the extraction of grape skins (\$931 per $1 \mathrm{~kg}$ of anthocyanins from grape cell suspension, compared to $\$ 2,083$ per $1 \mathrm{~kg}$ of anthocyanins, produced by grape skin extraction) [142]. However, the specific requirements of the available grape cell suspensions significantly complicate the scale up of the cultivation process, which is the serious restriction for realization of such biotechnological process.

\subsection{Pharmaceutical applications}

Anthocyanins have great potential for application in pharmaceutical products both as nutraceuticals and as therapeutic compounds. Frequent ingestion of anthocyanins could provide various health benefits including reduced risk of coronary heart diseases, anti-carcinogenic activity, antioxidant activity, reduced risk of stroke, anti-inflammatory effects etc. [13, 34, 184-186]. Biological activities of anthocyanin pigments have been already discussed in several excellent reviews [184, 187, 188]. Their pharmaceutical value has been additionally increased due to their high bioavailability. However, the administration and metabolism of anthocyanins in vivo have been investigated in details mostly in rats, whereas the detailed studies on humans still are scantly presented in scientific literature [60, 189]. For better understanding and investigation of anthocyanins absorption and in vivo metabolism in human and animal bodies, grape cell suspension culture of $V$. vinifera L. $c v$. Gamay Fréaux, was adapted to produce ${ }^{13} \mathrm{C}$-labeled anthocyanins (delphinidin-3-O-glucoside, cyanidin-3-O-glucoside 7, petunidin-3-O-glucoside, peonidin-3-O-glucoside and malvidin-3-O-glucoside) [190]. Development of reliable sources of isotopically labelled anthocyanins could have remarkable impact on advancement in diagnostic of metabolomic assimilation studies of these compounds in vivo.

\subsection{Food industry}

The world market of natural food colorants expands with the annual growth rate of 4-6\% [142]. In USA 4 of the 26 colorants approved by the food administration, that are exempt from certification, are based on anthocyanin pigments [34]. In European Union, all anthocyanin- 
containing colorants are classified as natural colorants under the classification E163 [191]. Currently most of the worldwide anthocyanins supply comes from processing of grape pomace, which is a waste product from winemaking. But in European Union other plant sources such as red cabbage, elderberry, black currant, purple carrot, sweet potato, and red radish are also allowed [192]. Anthocyanins, produced by grape cell suspensions can be a promising alternative supply of natural colorants. It has already been demonstrated that the produced pigments by the grape cell suspensions undergo significant structural modifications. Grape cell suspensions accumulates higher levels of metabolically more evolved structures (methylated and acylated anthocyanins). Acylated anthocyanins are suitable for application in food products, mainly because of the improved color stability compared to non-acylated structures [72]. Moreover, the grape cell suspensions can also produce elevated levels of beneficial phenolic compounds such as flavonoids, stilbenes, phenolics, etc., which are capable of increasing the added value of the final additive. The overall metabolite profile of grape cells in combination with the lack of microbial and toxic contaminations will give the potential for development of new types of food additives if the entire cell suspension biomass are utilized.

\subsection{Cosmetic industry}

The commercial interest of cosmetic companies to apply plant additives, derived by biotechnological cultivation of plant cells to their products has increased remarkably in the last few years [193]. The addition of plant cell derived extracts in cosmetic products has been considered as a powerful approach used to increase their health benefits. Several plant extracts have been added to various cosmetic products as moisturizers, antioxidants, whitening agents, colorants, sunscreens, preservatives etc. [193]. With the advancement of plant cell biotechnology, more and more cosmetic companies have been attracted for application of additives, based on plant cell suspensions. Recently the application of so-called plant "steam" cells attracts industry's attention [193]. In the last few years, the French company "Sederma" launched the product "Resistem $^{\mathrm{TM}}$ " based on application of in vitro cultivated plant cells (www.sederma.fr). The other company, "Mibelle Biochemistry", situated in Switzerland, developed a "PhytoCellTec" product, based on grape cell suspension of $V$. vinifera L. cv. Gamay Fréaux, which was processed by high-pressure homogenizer to produce liposomes for application in cream products (www.mibellebiochemistry.com). According to the company, the grape cell derived liposomes contained higher amounts of anthocyanins and when applied on skins serve as strong UV protectors and fight photoaging. The presented examples clearly demonstrate the commercial interest to application of grape cell suspension derived products. However, it is a matter of time for the scientists to develop the biotechnological approach of producing anthocyanins by grape cell suspensions from the frame of experimental scale to commercially applicable products.

\section{Conclusion and future prospects}

The approaches described in this chapter can be effective in improving novel anthocyaninderived metabolites in grape cell suspensions. Continuous study and exploitation of the knowledge of grape cell lines and their control mechanisms will open up new possibilities for 
metabolic engineering of the anthocyanin biosynthesis pathway. In parallel, the recent achievements in bioengineering with plant cell suspensions and the improvements of the existed bioreactor designs discovers new prospectives for commercial realization of anthocyanin producing technology based on cultivation of grape cells. This is a research area that is growing and gaining interest in the analysis of plant-based health-related compounds. Therefore, the full impact of metabolomics on muscadine research is yet to be experienced. But this chapter serves as a starting point for scientists who are interested in cell cultures from muscadine grapes.

\section{Acknowledgements}

The authors are grateful to the Florida A\&M University College of Agriculture and Food Science. The research work has been done with the financial support of USDA/NIFA/AFRI Plant Biochemistry Program Grant \# 2009-03127.

\section{Author details}

Anthony Ananga ${ }^{1}$, Vasil Georgiev ${ }^{1}$, Joel Ochieng ${ }^{2}$, Bobby Phills ${ }^{1}$ and Violeta Tsolova ${ }^{1}$

1 School of Agriculture and Food Sciences, Center for Vituculture and Small Fruit Research, Florida A\&M University, Tallahassee, FL, USA

2 Faculties of Agriculture and Veterinary Medicine, University of Nairobi, Nairobi, Kenya

\section{References}

[1] Deroles S. Anthocyanin biosynthesis in plant cell cultures: A potential source of natural colourants. In: C Winefield, K Davies and K Gould (Eds.) The Anthocyanins. Springer New York. 2009. pp108-167.

[2] Delgado-Vargas F., Jimenez A. R. and Paredes-Lopez O. Natural pigments: carotenoids, anthocyanins, and betalains - characteristics, biosynthesis, processing, and stability. Crit Rev Food Sci Nutr. 2000; 40(3) 173-289

[3] Georgiev V., Ilieva M., Bley T. and Pavlov A. Betalain production in plant in vitro systems. Acta Physiologiae Plantarum. 2008; 30(5) 581-593

[4] Pavokovic' D. and Krsnik-Rasol M. Complex biochemistry and biotechnological production of betalains. Food Technology and Biotechnology. 2011; 49(2) 145-155

[5] Tanaka Y., Sasaki N. and Ohmiya A. Biosynthesis of plant pigments: anthocyanins, betalains and carotenoids. The Plant Journal. 2008; 54(4) 733-749 
[6] Brockington S. F., Walker R. H., Glover B. J., Soltis P. S. and Soltis D. E. Complex pigment evolution in the Caryophyllales. New Phytologist. 2011; 190(4) 854-864

[7] Georgiev V. G., Bley T. and Pavlov A. I. Bioreactors for the cultivation of red beet hairy roots. In: B Neelwarne (Ed.) Red Beet Biotechnology. Springer US. 2012. pp251-281.

[8] Grotewold E. The genetics and biochemistry of floral pigments. Annu Rev Plant Biol. 2006; 57 761-780

[9] Mabry T. J. Selected topics from forty years of natural products research: Betalains to flavonoids, antiviral proteins, and neurotoxic nonprotein amino acids. Journal of Natural Products. 2001; 64(12) 1596-1604

[10] Harris N. N., Javellana J., Davies K. M., Lewis D. H., Jameson P. E., Deroles S. C., Calcott K. E., Gould K. S. and Schwinn K. E. Betalain production is possible in anthocyaninproducing plant species given the presence of DOPA-dioxygenase and L-DOPA. BMC Plant Biol. 2012; 1234

[11] Downham A. and Collins P. Colouring our foods in the last and next millennium. International Journal of Food Science \& Technology. 2000; 35(1) 5-22

[12] Ramachandra Rao S. and Ravishankar G. A. Plant cell cultures: Chemical factories of secondary metabolites. Biotechnology Advances. 2002; 20(2) 101-153

[13] Lila M. A. Anthocyanins and human health: An in vitro investigative approach. Journal of Biomedicine and Biotechnology. 2004; 2004(5) 306-313

[14] Koes R. E., Quattrocchio F. and Mol J. N. M. The flavonoid biosynthetic pathway in plants: Function and evolution. BioEssays. 1994; 16(2) 123-132

[15] Mazza G. and Francis F. J. Anthocyanins in grapes and grape products. Critical Reviews in Food Science and Nutrition. 1995; 35(4) 341-371

[16] Holton T. A. and Cornish E. C. Genetics and biochemistry of anthocyanin biosynthesis. Plant Cell. 1995; 7(7) 1071-1083

[17] Winkel-Shirley B. Flavonoid biosynthesis. A colorful model for genetics, biochemistry, cell biology, and biotechnology. Plant Physiol. 2001; 126(2) 485-493

[18] Koes R., Verweij W. and Quattrocchio F. Flavonoids: a colorful model for the regulation and evolution of biochemical pathways. Trends in Plant Science. 2005; 10(5) 236-242

[19] Jackman R. L., Yada R. Y., Tung M. A. and Speers R. A. Anthocyanins as food colorants - review. J. Food Biochem. . 1987; 11(3) 201-247

[20] Bitsch R., Netzel M., Frank T., Strass G. and Bitsch I. Bioavailability and biokinetics of anthocyanins from red grape juice and red wine. Journal of Biomedicine and Biotechnology. 2004; 2004(5) 293-298

[21] Castellarin S. D., Pfeiffer A., Sivilotti P., Degan M., Peterlunger E. and Di Gaspero G. Transcriptional regulation of anthocyanin biosynthesis in ripening fruits of grapevine under seasonal water deficit. Plant, Cell \& Environment. 2007; 30(11) 1381-1399 
[22] Zhang W. and Furusaki S. Production of anthocyanins by plant cell cultures. Biotechnology and Bioprocess Engineering. 1999; 4(4) 231-252

[23] Yesil-Celiktas O., Gurel A. and Vardar-Sukan F. Large scale cultivation of plant cell and tissue culture in bioreactors. Transworld Research Network 2010; 1-54

[24] Gould K. S. and Lister C. Flavonoid functions in plants. In: $\varnothing$ M Andersen and K R Markham (Eds.) Flavonoids: chemistry, biochemistry and applications. Boca Raton: CRC Press LLC. 2006. pp397-441.

[25] Lev-Yadun S. and Gould K. S. Role of anthocyanins in plant defence. In: C Winefield, K Davies and K Gould (Eds.) The Anthocyanins. Springer New York. 2009. pp22-28.

[26] Steyn W. J. Prevalence and functions of anthocyanins in fruits. In: C Winefield, K Davies and K Gould (Eds.) The Anthocyanins. Springer New York. 2009. pp86-105.

[27] Hatier J.-H. B. and Gould K. S. Anthocyanin function in vegetative organs. In: C Winefield, K Davies and K Gould (Eds.) The Anthocyanins. Springer New York. 2009. pp1-19.

[28] Andersen $\varnothing$. M. Recent advances in the field of anthocyanins - main focus on structures. In: F Daayf and V Lattanzio (Eds.) Recent advances in polyphenol research. Wiley-Blackwell. 2009. pp167-201.

[29] Andersen $\varnothing$. M. and Jordheim M. The Anthocyanins. In: $\varnothing$ M Andersen and K R Markham (Eds.) Flavonoids: chemistry, biochemistry and applications. Boca Raton: CRC Press LLC. 2006. pp471-553.

[30] Delgado-Vargas F. and Parades-López O (Eds.) Natural colorants for food and nutraceutical uses. Washington, D.C.: CRC Press Inc. ; 2003.

[31] Brat P., Tourniaire F. and Amiot-Carlin M. J. Stability and analysis of phenolic pigments. In: C Socaciu (Ed.) Food colorants, chemical and functional properties. New York: CRC Press. 2008. pp71-87.

[32] Conn S., Zhang W. and Franco C. Anthocyanic vacuolar inclusions (AVIs) selectively bind acylated anthocyanins in Vitis vinifera L. (grapevine) suspension culture. Biotechnol Lett. 2003; 25(11) 835-839

[33] Mercadante A. Z. and Bobbio F. O. Anthocyanins in foods: Occurrence and physicochemical properties. In: C Socaciu (Ed.) Food colorants, chemical and functional properties. New York: CRC Press. 2008. pp241-277.

[34] Wrolstad R. E. Anthocyanin pigments - bioactivity and coloring properties. Journal of Food Science. 2004; 69(5) C419-C425

[35] Pereira D., Valentão P., Pereira J. and Andrade P. Phenolics: From chemistry to biology. Molecules. 2009; 14(6) 2202-2211 
[36] Saito N., Tatsuzawa F., Miyoshi K., Shigihara A. and Honda T. The first isolation of Cglycosylanthocyanin from the flowers of Tricyrtis formosana. Tetrahedron Letters. 2003; 44(36) 6821-6823

[37] Tatsuzawa F., Saito N., Miyoshi K., Shinoda K., Shigihara A. and Honda T. Diacylated 8-C-Glucosylcyanidin 3-Glucoside from the Flowers of Tricyrtis formosana. Chemical and Pharmaceutical Bulletin. 2004; 52(5) 631-633

[38] Vogt T. Phenylpropanoid biosynthesis. Molecular Plant. 2010; 3(1) 2-20

[39] Dixon R. A. and Steele C. L. Flavonoids and isoflavonoids - a gold mine for metabolic engineering. Trends in Plant Science. 1999; 4(10) 394-400

[40] Dixon R. A., Xie D.-Y. and Sharma S. B. Proanthocyanidins - a final frontier in flavonoid research? New Phytologist. 2005; 165(1) 9-28

[41] Xie D.-Y. and Dixon R. A. Proanthocyanidin biosynthesis - still more questions than answers? Phytochemistry. 2005; 66(18) 2127-2144

[42] Tian L., Kong W. F., Pan Q. H., Zhan J. C., Wen P. F., Chen J. Y., Wan S. B. and Huang W. D. Expression of the chalcone synthase gene from grape and preparation of an antiCHS antibody. Protein Expression and Purification. 2006; 50(2) 223-228

[43] Sparvoli F., Martin C., Scienza A., Gavazzi G. and Tonelli C. Cloning and molecular analysis of structural genes involved in flavonoid and stilbene biosynthesis in grape (Vitis vinifera L.). Plant Molecular Biology. 1994; 24(5) 743-755

[44] Davies K. M. and Schwinn K. E. Molecular biology and biotechnology of flavonoid biosynthesis. In: $\varnothing \mathrm{M}$ Andersen and K R Markham (Eds.) Flavonoids: chemistry, biochemistry and applications. Boca Raton: CRC Press LLC. 2006. pp143-219.

[45] Veitch N. C. and Grayer R. J. Chalcones, dihydrochalcones, and aurones. In: $\varnothing \mathrm{M}$ Andersen and K R Markham (Eds.) Flavonoids: chemistry, biochemistry and applications. Boca Raton: CRC Press LLC. 2006. pp1003-1101.

[46] Goto-Yamamoto N., Wan G. H., Masaki K. and Kobayashi S. Structure and transcription of three chalcone synthase genes of grapevine (Vitis vinifera). Plant Science. 2002; 162(6) $867-872$

[47] Ageorges A., Fernandez L., Vialet S., Merdinoglu D., Terrier N. and Romieu C. Four specific isogenes of the anthocyanin metabolic pathway are systematically co-expressed with the red colour of grape berries. Plant Science. 2006; 170(2) 372-383

[48] He F., Mu L., Yan G.-L., Liang N.-N., Pan Q.-H., Wang J., Reeves M. J. and Duan C.-Q. Biosynthesis of anthocyanins and their regulation in colored grapes. Molecules. 2010; 15(12) 9057-9091

[49] Gutha L. R., Casassa L. F., Harbertson J. F. and Naidu R. A. Modulation of flavonoid biosynthetic pathway genes and anthocyanins due to virus infection in grapevine (Vitis vinifera L.) leaves. BMC Plant Biol. 2010; 10187 
[50] Markham K. R., Gould K. S., Winefield C. S., Mitchell K. A., Bloor S. J. and Boase M. R. Anthocyanic vacuolar inclusions - their nature and significance in flower colouration. Phytochemistry. 2000; 55(4) 327-336

[51] Conn S., Franco C. and Zhang W. Characterization of anthocyanic vacuolar inclusions in Vitis vinifera L. cell suspension cultures. Planta. 2010; 231(6) 1343-1360

[52] Leão P. C. d. S., Cruz C. D. and Motoike S. Y. Genetic diversity of table grape based on morphoagronomic traits. Scientia Agricola. 2011; 68 42-49

[53] Leão P. C. d. S. and Motoike S. Y. Genetic diversity in table grapes based on RAPD and microsatellite markers. Pesquisa Agropecuária Brasileira. 2011; 46 1035-1044

[54] This P., Lacombe T., Cadle-Davidson M. and Owens C. Wine grape (Vitis vinifera L.) color associates with allelic variation in the domestication gene VvmybA1. TAG Theoretical and Applied Genetics. 2007; 114(4) 723-730

[55] Azuma A., Kobayashi S., Yakushiji H., Yamada M., Mitani N. and Sato A. VvmybA1 genotype determines grape sin color. Vitis. 2007; 46(3) 154-155

[56] Kobayashi S., Goto-Yamamoto N. and Hirochika H. Retrotransposon-induced mutations in grape skin color. Science. 2004; 304(5673) 982

[57] Zhao Q., Duan C.-Q. and Wang J. Anthocyanins profile of grape berries of Vitis amurensis, Its hybrids and their wines. International Journal of Molecular Sciences. 2010; 11(5) 2212-2228

[58] Boss P. K. and Davies C. Molecular biology of sugar and anthocyanin accumulation in grape berries. In: K A Roubelakis-Angelakis (Ed.) Molecular biology \& biotechnology of the grapevine. London: Kluwer Academic Publishers. 2001. pp1-34.

[59] Boss P. K., Davies C. and Robinson S. P. Anthocyanin composition and anthocyanin pathway gene expression in grapevine sports differing in berry skin colour. Australian Journal of Grape and Wine Research. 1996; 2(3) 163-170

[60] He J. and Giusti M. M. Anthocyanins: natural colorants with health-promoting properties. Annu Rev Food Sci Technol. 2010; 1 163-187

[61] Boss P. K., Davies C. and Robinson S. P. Analysis of the expression of anthocyanin pathway genes in developing Vitis vinifera L. cv Shiraz grape berries and the implications for pathway regulation. Plant Physiol. 1996; 111(4) 1059-1066

[62] Ballinger W. E., Maness E. P., Nesbitt W. B. and Carroll D. E. Anthocyanins of black grapes of 10 clones of Vitis rotundifolia, Michx. Journal of Food Science. 1973; 38(5) 909-910

[63] Huang Z., Wang B., Williams P. and Pace R. D. Identification of anthocyanins in muscadine grapes with HPLC-ESI-MS. LWT - Food Science and Technology. 2009; 42(4) 819-824 
[64] Sandhu A. K., Gray D. J., Lu J. and Gu L. Effects of exogenous abscisic acid on antioxidant capacities, anthocyanins, and flavonol contents of muscadine grape (Vitis rotundifolia) skins. Food Chemistry. 2011; 126(3) 982-988

[65] Jánváry L. s., Hoffmann T., Pfeiffer J., Hausmann L., Töpfer R., Fischer T. C. and Schwab W. A double mutation in the anthocyanin 5-O-glucosyltransferase gene disrupts enzymatic activity in Vitis vinifera L. Journal of Agricultural and Food Chemistry. 2009; 57(9) 3512-3518

[66] Cravero M. C., Guidoni S., Schneider A. and De Stefano R. Caractérisation variétale de cépages musqués à raisin coloré au moyen de paramètres ampélographiques descriptifs et biochimiques. Vitis. 1994; 33(2) 75-80

[67] $\mathrm{Wu}$ X. and Prior R. L. Systematic identification and characterization of anthocyanins by HPLC-ESI-MS/MS in common foods in the United States: fruits and berries. Journal of Agricultural and Food Chemistry. 2005; 53(7) 2589-2599

[68] Lücker J., Martens S. and Lund S. T. Characterization of a Vitis vinifera cv. Cabernet Sauvignon 3', 5'-O-methyltransferase showing strong preference for anthocyanins and glycosylated flavonols. Phytochemistry. 2010; 71(13) 1474-1484

[69] Davis G., Ananga A., Krastanova S., Sutton S., Ochieng J. W., Leong S. and Tsolova V. Elevated gene expression in chalcone synthase enzyme suggests an increased production of flavonoids in skin and synchronized red cell cultures of North American native grape berries. DNA Cell Biol. 2012; 31(6) 939-945

[70] Samuelian S. K., Camps C., Kappel C., Simova E. P., Delrot S. and Colova V. M. Differential screening of overexpressed genes involved in flavonoid biosynthesis in North American native grapes: 'Noble' muscadinia var. and 'Cynthiana' aestivalis var. Plant Science. 2009; 177(3) 211-221

[71] Fournier-Level A., Hugueney P., Verries C., This P. and Ageorges A. Genetic mechanisms underlying the methylation level of anthocyanins in grape (Vitis vinifera $\mathrm{L}$.). BMC Plant Biology. 2011; 11(1) 179

[72] Bakowska-Barczak A. Acylated anthocyanins as stable, natural food colorants - a review. Polish Journal of Food and Nutrition Sciences. 2005; 14(2) 107-116

[73] Flora L. F. Influence of heat, cultivar and maturity on the anthocyanidin-3,5-diglucosides of Muscadine grapes. Journal of Food Science. 1978; 43(6) 1819-1821

[74] Baluja J., Diago M., Goovaerts P. and Tardaguila J. Assessment of the spatial variability of anthocyanins in grapes using a fluorescence sensor: relationships with vine vigour and yield. Precision Agriculture. 2012; 13(4) 457-472

[75] Tuccio L., Remorini D., Pinelli P., Fierini E., Tonutti P., Scalabrelli G. and Agati G. Rapid and non-destructive method to assess in the vineyard grape berry anthocyanins under different seasonal and water conditions. Australian Journal of Grape and Wine Research. 2011; 17(2) 181-189 
[76] Broun P. Transcriptional control of flavonoid biosynthesis: a complex network of conserved regulators involved in multiple aspects of differentiation in Arabidopsis. Current Opinion in Plant Biology. 2005; 8(3) 272-279

[77] Ramsay N. A. and Glover B. J. MYB-bHLH-WD40 protein complex and the evolution of cellular diversity. Trends in Plant Science. 2005; 10(2) 63-70

[78] Petroni K. and Tonelli C. Recent advances on the regulation of anthocyanin synthesis in reproductive organs. Plant Science. 2011; 181(3) 219-229

[79] Schwinn K. E. and Davies K. M. Flavonoids. In: K Davies (Ed.) Plant Pigments and their Manipulation. Oxford: Blackwell Publishing Ltd. 2004. pp92-149.

[80] Springob K., Nakajima J.-i., Yamazaki M. and Saito K. Recent advances in the biosynthesis and accumulation of anthocyanins. Natural Product Reports. 2003; 20(3) 288-303

[81] He F., Pan Q.-H., Shi Y. and Duan C.-Q. Biosynthesis and genetic regulation of proanthocyanidins in plants. Molecules. 2008; 13(10) 2674-2703

[82] Abrahams S., Tanner G. J., Larkin P. J. and Ashton A. R. Identification and biochemical characterization of mutants in the proanthocyanidin pathway in Arabidopsis. Plant Physiol. 2002; 130(2) 561-576

[83] Ramsay N. A., Walker A. R., Mooney M. and Gray J. C. Two basic-helix-loop-helix genes (MYC-146 and GL3) from Arabidopsis can activate anthocyanin biosynthesis in a white-flowered Matthiola incana mutant. Plant Molecular Biology. 2003; 52(3) 679-688

[84] Gonzalez A., Zhao M., Leavitt J. M. and Lloyd A. M. Regulation of the anthocyanin biosynthetic pathway by the TTG1/bHLH/Myb transcriptional complex in Arabidopsis seedlings. The Plant Journal. 2008; 53(5) 814-827

[85] Dubos C., Le Gourrierec J., Baudry A., Huep G., Lanet E., Debeaujon I., Routaboul J.M., Alboresi A., Weisshaar B. and Lepiniec L. MYBL2 is a new regulator of flavonoid biosynthesis in Arabidopsis thaliana. The Plant Journal. 2008; 55(6) 940-953

[86] Deluc L., Barrieu F., Marchive C., Lauvergeat V., Decendit A., Richard T., Carde J. P., Merillon J. M. and Hamdi S. Characterization of a grapevine R2R3-MYB transcription factor that regulates the phenylpropanoid pathway. Plant Physiol. 2006; 140(2) 499-511

[87] Deluc L., Bogs J., Walker A. R., Ferrier T., Decendit A., Merillon J. M., Robinson S. P. and Barrieu F. The transcription factor $V v M Y B 5 b$ contributes to the regulation of anthocyanin and proanthocyanidin biosynthesis in developing grape berries. Plant Physiol. 2008; 147(4) 2041-2053

[88] Kobayashi S. K., Ishimaru M. I., Hiraoka K. H. and Honda C. H. Myb-related genes of the Kyoho grape (Vitis labruscana) regulate anthocyanin biosynthesis. Planta. 2002; 215(6) 924-933

[89] Walker A. R., Lee E., Bogs J., McDavid D. A. J., Thomas M. R. and Robinson S. P. White grapes arose through the mutation of two similar and adjacent regulatory genes. The Plant Journal. 2007; 49(5) 772-785 
[90] Bogs J., Downey M. O., Harvey J. S., Ashton A. R., Tanner G. J. and Robinson S. P. Proanthocyanidin synthesis and expression of genes encoding leucoanthocyanidin reductase and anthocyanidin reductase in developing grape berries and grapevine leaves. Plant Physiol. 2005; 139(2) 652-663

[91] Kobayashi S., Goto-Yamamoto N. and Hirochika H. Association of VvmybAl gene expression with anthocyanin production in grape (Vitis vinifera) skin-color mutants. Journal of the Japanese Society for Horticultural Science 2005; 74(3) 196-203

[92] Azuma A., Kobayashi S., Mitani N., Shiraishi M., Yamada M., Ueno T., Kono A., Yakushiji H. and Koshita Y. Genomic and genetic analysis of $M y b$-related genes that regulate anthocyanin biosynthesis in grape berry skin. TAG Theoretical and Applied Genetics. 2008; 117(6) 1009-1019

[93] Colova V. Synchronized strains of subepidermal cells of muscadine (muscadine sp.) grapevine pericarp for use as a sourse of flavonoids (nutraceuticals). United States. 2011 20110054195.

[94] Ananga A., Krastanova K., Sutton S. and Colova V. Molecular assessments of synchronized in vitro red cell cultures of American native grapes. Proc. Fla. State Hort. Soc. 2011; 124 7-12

[95] van der Krol A. R., Mur L. A., Beld M., Mol J. N. and Stuitje A. R. Flavonoid genes in Petunia: addition of a limited number of gene copies may lead to a suppression of gene expression. Plant Cell. 1990; 2(4) 291-299

[96] van der Krol A. R., Lenting P. E., Veenstra J., van der Meer I. M., Koes R. E., Gerats A. G. M., Mol J. N. M. and Stuitje A. R. An anti-sense chalcone synthase gene in transgenic plants inhibits flower pigmentation. Nature. 1988; 333(6176) 866-869

[97] Courtney-Gutterson N., Napoli C., Lemieux C., Morgan A., Firoozabady E. and Robinson K. E. P. Modification of flower color in florist's chrysanthemum: Production of a white-flowering variety through molecular genetics. Nat Biotech. 1994; 12(3) 268-271

[98] Butelli E., Titta L., Giorgio M., Mock H.-P., Matros A., Peterek S., Schijlen E. G. W. M., Hall R. D., Bovy A. G., Luo J. and Martin C. Enrichment of tomato fruit with healthpromoting anthocyanins by expression of select transcription factors. Nat Biotech. 2008; 26(11) 1301-1308

[99] Mol J., Cornish E., Mason J. and Koes R. Novel coloured flowers. Current Opinion in Biotechnology. 1999; 10(2) 198-201

[100] Suzuki H., Nakayama T., Yonekura-Sakakibara K., Fukui Y., Nakamura N., Yamaguchi M. A., Tanaka Y., Kusumi T. and Nishino T. cDNA cloning, heterologous expressions, and functional characterization of malonyl-coenzyme a:anthocyanidin 3-o-glucoside-6"-o-malonyltransferase from dahlia flowers. Plant Physiol. 2002; 130(4) 2142-2151

[101] Zuker A., Tzfira T., Ben-Meir H., Ovadis M., Shklarman E., Itzhaki H., Forkmann G., Martens S., Neta-Sharir I., Weiss D. and Vainstein A. Modification of flower color and 
fragrance by antisense suppression of the flavanone 3-hydroxylase gene. Molecular Breeding. 2002; 9(1) 33-41

[102] Fukui Y., Tanaka Y., Kusumi T., Iwashita T. and Nomoto K. A rationale for the shift in colour towards blue in transgenic carnation flowers expressing the flavonoid $3^{\prime}, 5^{\prime}$ hydroxylase gene. Phytochemistry. 2003; 63(1) 15-23

[103] Bovy A., Schijlen E. and Hall R. Metabolic engineering of flavonoids in tomato (Solanum lycopersicum): the potential for metabolomics. Metabolomics. 2007; 3(3) 399-412

[104] Schijlen E. G. W. M., Ric de Vos C. H., van Tunen A. J. and Bovy A. G. Modification of flavonoid biosynthesis in crop plants. Phytochemistry. 2004; 65(19) 2631-2648

[105] Khachik F., Carvalho L., Bernstein P. S., Muir G. J., Zhao D.-Y. and Katz N. B. Chemistry, distribution, and metabolism of tomato carotenoids and their impact on human health. Experimental Biology and Medicine. 2002; 227(10) 845-851

[106] Mes P. J., Boches P., Myers J. R. and Durst R. Characterization of tomatoes expressing anthocyanin in the fruit. Journal of the American Society for Horticultural Science. 2008; 133(2) 262-269

[107] Gonzali S., Mazzucato A. and Perata P. Purple as a tomato: towards high anthocyanin tomatoes. Trends in Plant Science. 2009; 14(5) 237-241

[108] Muir S. R., Collins G. J., Robinson S., Hughes S., Bovy A., Ric De Vos C. H., van Tunen A. J. and Verhoeyen M. E. Overexpression of petunia chalcone isomerase in tomato results in fruit containing increased levels of flavonols. Nat Biotech. 2001; 19(5) 470-474

[109] Bovy A., de Vos R., Kemper M., Schijlen E., Almenar Pertejo M., Muir S., Collins G., Robinson S., Verhoeyen M., Hughes S., Santos-Buelga C. and van Tunen A. Highflavonol tomatoes resulting from the heterologous expression of the maize transcription factor genes LC and C1. Plant Cell. 2002; 14(10) 2509-2526

[110] Verhoeyen M. E., Bovy A., Collins G., Muir S., Robinson S., de Vos C. H. R. and Colliver S. Increasing antioxidant levels in tomatoes through modification of the flavonoid biosynthetic pathway. Journal of Experimental Botany. 2002; 53(377) 2099-2106

[111] Luo J., Butelli E., Hill L., Parr A., Niggeweg R., Bailey P., Weisshaar B. and Martin C. AtMYB12 regulates caffeoyl quinic acid and flavonol synthesis in tomato: expression in fruit results in very high levels of both types of polyphenol. The Plant Journal. 2008; 56(2) 316-326

[112] Ranish J. A. and Hahn S. Transcription: basal factors and activation. Current opinion in genetics \& development. 1996; 6(2) 151-158

[113] Hernandez J. M., Heine G. F., Irani N. G., Feller A., Kim M.-G., Matulnik T., Chandler V. L. and Grotewold E. Different mechanisms participate in the R-dependent activity of the R2R3 MYB transcription factor C1. Journal of Biological Chemistry. 2004; 279(46) $48205-48213$ 
[114] Schwinn K., Venail J., Shang Y., Mackay S., Alm V., Butelli E., Oyama R., Bailey P., Davies K. and Martin C. A small family of $M Y B$-regulatory genes controls floral pigmentation intensity and patterning in the genus Antirrhinum. The Plant Cell Online. 2006; 18(4) 831-851

[115] Morita Y., Saitoh M., Hoshino A., Nitasaka E. and Iida S. Isolation of cDNAs for R2R3MYB, bHLH and WDR transcriptional regulators and identification of $\mathrm{c}$ and ca mutations conferring white flowers in the Japanese morning glory. Plant and Cell Physiology. 2006; 47(4) 457-470

[116] Quattrocchio F., Wing J. F., Leppen H., Mol J. and Koes R. E. Regulatory genes controlling anthocyanin pigmentation are functionally conserved among plant species and have distinct sets of target genes. The Plant Cell Online. 1993; 5(11) 1497-1512

[117] Aharoni A., De Vos C. H. R., Wein M., Sun Z., Greco R., Kroon A., Mol J. N. M. and O'Connell A. P. The strawberry FaMYB1 transcription factor suppresses anthocyanin and flavonol accumulation in transgenic tobacco. The Plant Journal. 2001; 28(3) 319-332

[118] Mathews H., Clendennen S. K., Caldwell C. G., Liu X. L., Connors K., Matheis N., Schuster D. K., Menasco D. J., Wagoner W., Lightner J. and Wagner D. R. Activation tagging in tomato identifies a transcriptional regulator of anthocyanin biosynthesis, modification, and transport. The Plant Cell Online. 2003; 15(8) 1689-1703

[119] Sutton S., Krastanova S., Ananga A., Leong S. and Tsolova V. Genetic transformation for overexpression of flavonoid compounds in Muscadinia grape cell cultures. Proc. Fla. State Hort. Soc. 2011; 124 13-17

[120] Le Gall G., DuPont M. S., Mellon F. A., Davis A. L., Collins G. J., Verhoeyen M. E. and Colquhoun I. J. Characterization and content of flavonoid glycosides in genetically modified tomato (Lycopersicon esculentum) fruits. Journal of Agricultural and Food Chemistry. 2003; 51(9) 2438-2446

[121] Lloyd A. M., Walbot V. and Davis R. W. Arabidopsis and Nicotiana anthocyanin production activated by maize regulators R and C1. Science (New York, N.Y.). 1992; 258(5089) 1773-1775

[122] Goldsbrough A. P., Tong Y. and Yoder J. I. Lc as a non-destructive visual reporter and transposition excision marker gone for tomato. The Plant Journal. 1996; 9(6) 927-933

[123] Bino R. J., De Vos C. H. R., Lieberman M., Hall R. D., Bovy A., Jonker H. H., Tikunov Y., Lommen A., Moco S. and Levin I. The light-hyperresponsive high pigment-2dg mutation of tomato: alterations in the fruit metabolome. New Phytologist. 2005; 166(2) 427-438

[124] Davuluri G. R., van Tuinen A., Fraser P. D., Manfredonia A., Newman R., Burgess D., Brummell D. A., King S. R., Palys J., Uhlig J., Bramley P. M., Pennings H. M. J. and Bowler C. Fruit-specific RNAi-mediated suppression of Det-1 enhances carotenoid and flavonoid content in tomatoes. Nat Biotech. 2005; 23(7) 890-895 
[125] Beld M., Martin C., Huits H., Stuitje A. R. and Gerats A. G. M. Flavonoid synthesis in Petunia hybrida: partial characterization of dihydroflavonol-4-reductase genes. Plant Molecular Biology. 1989; 13(5) 491-502

[126] Cone K. C., Burr F. A. and Burr B. Molecular analysis of the maize anthocyanin regulatory locus C1. Proceedings of the National Academy of Sciences. 1986; 83(24) 9631-9635

[127] Coombe B. and Bishop G. Development of the grape berry. II. Changes in diameter and deformability during veraison. Australian Journal of Agricultural Research. 1980; 31(3) 499-509

[128] Colliver S., Bovy A., Collins G., Muir S., Robinson S., de Vos C. H. R. and Verhoeyen M. E. Improving the nutritional content of tomatoes through reprogramming their flavonoid biosynthetic pathway. Phytochemistry Reviews. 2002; 1(1) 113-123

[129] Miyao A., Tanaka K., Murata K., Sawaki H., Takeda S., Abe K., Shinozuka Y., Onosato K. and Hirochika H. Target site specificity of the Tos17 retrotransposon shows a preference for insertion within genes and against insertion in retrotransposon-rich regions of the genome. Plant Cell. 2003; 15(8) 1771-1780

[130] Terada R., Urawa H., Inagaki Y., Tsugane K. and Iida S. Efficient gene targeting by homologous recombination in rice. Nat Biotechnol. 2002; 20(10) 1030-1034

[131] Zamecnik P. C. and Stephenson M. L. Inhibition of Rous sarcoma virus replication and cell transformation by a specific oligodeoxynucleotide. Proceedings of the National Academy of Sciences. 1978; 75(1) 280-284

[132] Napoli C., Lemieux C. and Jorgensen R. Introduction of a chimeric chalcone synthase gene into Petunia results in reversible co-suppression of homologous genes in trans. Plant Cell. 1990; 2(4) 279-289

[133] Fire A., Xu S., Montgomery M. K., Kostas S. A., Driver S. E. and Mello C. C. Potent and specific genetic interference by double-stranded RNA in Caenorhabditis elegans. Nature. 1998; 391(6669) 806-811

[134] Waterhouse P. M., Wang M.-B. and Finnegan E. J. Role of short RNAs in gene silencing. Trends in Plant Science. 2001; 6(7) 297-301

[135] Schijlen E. G. W. M. Genetic engineering of flavonoid biosynthesis in tomato. PhD Thesis. Amsterdam, Universiteit van Amsterdam. 2007

[136] Bernstein E., Caudy A. A., Hammond S. M. and Hannon G. J. Role for a bidentate ribonuclease in the initiation step of RNA interference. Nature. 2001; 409(6818) 363-366

[137] Sharp P. A. RNA interference. Genes Dev. 2001; 15(5) 485-490

[138] Meins F. RNA degradation and models for post-transcriptional gene silencing. Plant Molecular Biology. 2000; 43(2) 261-273 
[139] Hammond S. M., Bernstein E., Beach D. and Hannon G. J. An RNA-directed nuclease mediates post-transcriptional gene silencing in Drosophila cells. Nature. 2000; 404(6775) 293-296

[140] Colova (Tsolova) V. M., Bordallo P. N., Phills B. R. and Bausher M. Synchronized somatic embryo development in embryogenic suspensions of grapevine Muscadinia rotundifolia (Michx.) Small. Vitis. 2007; 46(1) 15-18

[141] Conn S., Curtin C., Bézier A., Franco C. and Zhang W. Purification, molecular cloning, and characterization of glutathione S-transferases (GSTs) from pigmented Vitis vinifera L. cell suspension cultures as putative anthocyanin transport proteins. Journal of Experimental Botany. 2008; 59(13) 3621-3634

[142] Cormier F., Brion F., Do C. B. and Moresoli C. Development of process strategies for anthocyanin-based food colorant production using Vitis vinifera cell cultures. In: F DiCosmo and M Misawa (Eds.) Plant cell culture secondary metabolism toward industrial application. CRC Press LLC. 1996. pp167-186.

[143] Zhang W., Franco C., Curtin C. and Conn S. To stretch the boundary of secondary metabolite production in plant cell-based bioprocessing: anthocyanin as a case study. Journal of biomedicine E biotechnology. 2004; 2004(5) 264-271

[144] Lazar A. and Petolescu C. Experimental results concerning the synthesized anthocyanin amount in the Vitis vinifera L. suspension cell culture in the laboratory bioreactor. Journal of Horticulture, Forestry and Biotechnology. 2009; 13 443-446

[145] Guan L., Li J.-H., Fan P.-G., Chen S., Fang J.-B., Li S.-H. and Wu B.-H. Anthocyanin accumulation in various organs of a teinturier grape cultivar ( $V$. vinifera L.) during the growing season. American Journal of Enology and Viticulture. 2012; DOI: 10.5344/ajev. 2011.11063

[146] Krisa S., Vitrac X., Decendit A., Larronde F., Deffieux G. and Mérillon J.-M. Obtaining Vitis vinifera cell cultures producing higher amounts of malvidin-3-O- $\beta$-glucoside. Biotechnology Letters. 1999; 21(6) 497-500

[147] Torregrosa L., Bouquet A. and Goussard P. G. In vitro culture and propagation of grapevine. In: K A Roubelakis-Angelakis (Ed.) Molecular biology \& biotechnology of the grapevine. London: Kluwer Academic Publishers. 2001. pp281-326.

[148] Marchev A., Georgiev V., Ivanov I., Badjakov I. and Pavlov A. Two-phase temporary immersion system for Agrobacterium rhizogenes genetic transformation of sage (Salvia tomentosa Mill.). Biotechnology Letters. 2011; 33(9) 1873-1878

[149] Velcheva M., Faltin Z., Vardi A., Hanania U., Eshdat Y., Dgani O., Sahar N. and Perl A. Aloe vera transformation: the role of Amberlite XAD-4 resin and antioxidants during selection and regeneration. In Vitro Cellular \& Developmental Biology - Plant. 2010; 46(6) 477-484 
[150] Qu J., Zhang W., Yu X. and Jin M. Instability of anthocyanin accumulation in Vitis vinifera L. var. Gamay Fréaux suspension cultures. Biotechnology and Bioprocess Engineering. 2005; 10(2) 155-161

[151] Qu J., Zhang W. and Yu X. A combination of elicitation and precursor feeding leads to increased anthocyanin synthesis in cell suspension cultures of Vitis vinifera. Plant Cell, Tissue and Organ Culture. 2011; 107(2) 261-269

[152] Baublis A., Spomer A. R. T. and Berber-JimÉNez M. D. Anthocyanin pigments: comparison of extract stability. Journal of Food Science. 1994; 59(6) 1219-1221

[153] Mewis I., Smetanska I., Müller C. and Ulrichs C. Specific poly-phenolic compounds in cell culture of Vitis vinifera L. cv. Gamay Fréaux. Applied Biochemistry and Biotechnology. 2011; 164(2) 148-161

[154] Dédaldéchamp F. and Uhel C. Induction of anthocyanin synthesis in nonpigmented grape cell suspensions by acting on DFR substrate availability or precursors level. Enzyme and Microbial Technology. 1999; 25(3-5) 316-321

[155] Nagamori E., Hiraoka K., Honda H. and Kobayashi T. Enhancement of anthocyanin production from grape (Vitis vinifera) callus in a viscous additive-supplemented medium. Biochemical Engineering Journal. 2001; 9(1) 59-65

[156] Pavlov A., Georgiev V. and Kovatcheva P. Relationship between type and age of the inoculum cultures and betalains biosynthesis by Beta vulgaris hairy root culture. Biotechnology Letters. 2003; 25(4) 307-309

[157] Nagella P., Chung I.-M. and Murthy H. N. In vitro production of gymnemic acid from cell suspension cultures of Gymnema sylvestre R. Br. Engineering in Life Sciences. 2011; 11(5) 537-540

[158] Decendit A. and Mérillon J. M. Condensed tannin and anthocyanin production in Vitis vinifera cell suspension cultures. Plant Cell Reports. 1996; 15(10) 762-765

[159] Yin Y., Borges G., Sakuta M., Crozier A. and Ashihara H. Effect of phosphate deficiency on the content and biosynthesis of anthocyanins and the expression of related genes in suspension-cultured grape (Vitis sp.) cells. Plant Physiology and Biochemistry. 2012; 55(0) $77-84$

[160] Hirasuna T. J., Shuler M. L., Lackney V. K. and Spanswick R. M. Enhanced anthocyanin production in grape cell cultures. Plant Science. 1991; 78(1) 107-120

[161] Larronde F., Krisa S., Decendit A., Chèze C., Deffieux G. and Mérillon J. M. Regulation of polyphenol production in Vitis vinifera cell suspension cultures by sugars. Plant Cell Reports. 1998; 17(12) 946-950

[162] Suzuki M. Enhancement of anthocyanin accumulation by high osmotic stress and low pH in grape cells (Vitis hybrids). Journal of Plant Physiology. 1995; 147(1) 152-155

[163] Hiroyuki H., Kousuke H., Eiji N., Mariko O., Yoshihito K., Setsuro H. and Takeshi K. Enhanced anthocyanin production from grape callus in an air-lift type bioreactor using 
a viscous additive-supplemented medium. Journal of Bioscience and Bioengineering. 2002; 94(2) 135-139

[164] Iercan C. and Nedelea G. Experimental results concerning the effect of culture medium $\mathrm{pH}$ on the synthesized anthocyanin amount in the callus culture of Vitis vinifera L. Journal of Horticulture, Forestry and Biotechnology. 2012; 16(2) 71-73

[165] Christie P. J., Alfenito M. R. and Walbot V. Impact of low-temperature stress on general phenylpropanoid and anthocyanin pathways: Enhancement of transcript abundance and anthocyanin pigmentation in maize seedlings. Planta. 1994; 194(4) 541-549

[166] Chalker-Scott L. Environmental significance of anthocyanins in plant stress responses. Photochemistry and Photobiology. 1999; 70(1) 1-9

[167] Yamane T., Jeong S. T., Goto-Yamamoto N., Koshita Y. and Kobayashi S. Effects of temperature on anthocyanin biosynthesis in grape berry skins. American Journal of Enology and Viticulture. 2006; 57(1) 54-59

[168] Mori K., Goto-Yamamoto N., Kitayama M. and Hashizume K. Loss of anthocyanins in red-wine grape under high temperature. Journal of Experimental Botany. 2007; 58(8) 1935-1945

[169] Azuma A., Yakushiji H., Koshita Y. and Kobayashi S. Flavonoid biosynthesis-related genes in grape skin are differentially regulated by temperature and light conditions. Planta. 2012; 236(4) 1067-1080

[170] Zhang Z.-Z., Li X.-X., Chu Y.-N., Zhang M.-X., Wen Y.-Q., Duan C.-Q. and Pan Q.-H. Three types of ultraviolet irradiation differentially promote expression of shikimate pathway genes and production of anthocyanins in grape berries. Plant Physiology and Biochemistry. 2012; 57(0) 74-83

[171] Lazar A., Petolescu C. and Popescu S. Experimental results concerning the effect of photoperiod and callus culture duration on anthocyanin amount. Journal of Horticulture, Forestry and Biotechnology. 2010; 14(2) 153-157

[172] Curtin C., Zhang W. and Franco C. Manipulating anthocyanin composition in Vitis vinifera suspension cultures by elicitation with jasmonic acid and light irradiation. Biotechnol Lett. 2003; 25(14) 1131-1135

[173] Zhang W., Curtin C., Kikuchi M. and Franco C. Integration of jasmonic acid and light irradiation for enhancement of anthocyanin biosynthesis in Vitis vinifera suspension cultures. Plant Science. 2002; 162(3) 459-468

[174] Gagné S., Cluzet S., Mérillon J.-M. and Gény L. ABA initiates anthocyanin production in grape cell cultures. Journal of Plant Growth Regulation. 2011; 30(1) 1-10

[175] Zhao J., Davis L. C. and Verpoorte R. Elicitor signal transduction leading to production of plant secondary metabolites. Biotechnol Adv. 2005; 23(4) 283-333

[176] Cai Z., Riedel H., Thaw Saw N., Kütük O., Mewis I., Jäger H., Knorr D. and Smetanska I. Effects of pulsed electric field on secondary metabolism of Vitis vinifera L. cv. Gamay 
Fréaux suspension culture and exudates. Applied Biochemistry and Biotechnology. 2011; 164(4) 443-453

[177] Cai Z., Riedel H., Saw N. M. M. T., Mewis I., Reineke K., Knorr D. and Smetanska I. Effects of elicitors and high hydrostatic pressure on secondary metabolism of Vitis vinifera suspension culture. Process Biochemistry. 2011; 46(7) 1411-1416

[178] Cai Z., Knorr D. and Smetanska I. Enhanced anthocyanins and resveratrol production in Vitis vinifera cell suspension culture by indanoyl-isoleucine, N-linolenoyl-l-glutamine and insect saliva. Enzyme and Microbial Technology. 2012; 50(1) 29-34

[179] Cai Z., Kastell A., Mewis I., Knorr D. and Smetanska I. Polysaccharide elicitors enhance anthocyanin and phenolic acid accumulation in cell suspension cultures of Vitis vinifera. Plant Cell, Tissue and Organ Culture. 2012; 108(3) 401-409

[180] Saw N., Riedel H., Cai Z., Kütük O. and Smetanska I. Stimulation of anthocyanin synthesis in grape (Vitis vinifera) cell cultures by pulsed electric fields and ethephon. Plant Cell, Tissue and Organ Culture. 2012; 108(1) 47-54

[181] Santamaria A. R., Mulinacci N., Valletta A., Innocenti M. and Pasqua G. Effects of elicitors on the production of resveratrol and viniferins in cell cultures of Vitis vinifera L. cv Italia. Journal of Agricultural and Food Chemistry. 2011; 59(17) 9094-9101

[182] Riedel H., Akumo D. N., Saw N. M. M. T., Kütük O., Neubauer P. and Smetanska I. Elicitation and precursor feeding influence phenolic acids composition in Vitis vinifera suspension culture. African Journal of Biotechnology. 2012; 11(12) 3000-3008

[183] Sinilal B., Ovadia R., Nissim-Levi A., Perl A., Carmeli-Weissberg M. and Oren-Shamir M. Increased accumulation and decreased catabolism of anthocyanins in red grape cell suspension culture following magnesium treatment. Planta. 2011; 234(1) 61-71

[184] Lila M. A. Plant pigments and human health. In: K Davies (Ed.) Plant Pigments and their Manipulation. Oxford: Blackwell Publishing Ltd. 2004. pp248-274.

[185] Wallace T. C. Anthocyanins in cardiovascular disease. Adv Nutr. 2011; 2(1) 1-7

[186] Mazza G. and Kay C. D. Bioactivity, absorption, and metabolism of anthocyanins. In: F Daayf and V Lattanzio (Eds.) Recent Advances in Polyphenol Research. WileyBlackwell. 2009. pp228-262.

[187] Stintzing F. C. and Carle R. Functional properties of anthocyanins and betalains in plants, food, and in human nutrition. Trends in Food Science Eamp; Technology. 2004; 15(1) 19-38

[188] Amiot-Carlin M. J., Babot-Laurent C. and Tourniaire F. Plant pigments as bioactive substances. In: C Socaciu (Ed.) Food colorants, chemical and functional properties. New York: CRC Press. 2008. pp127-147.

[189] Yue X., Zhang W. and Deng M. Hyper-production of 13C-labeled trans-resveratrol in Vitis vinifera suspension cell culture by elicitation and in situ adsorption. Biochemical Engineering Journal. 2011; 53(3) 292-296 
[190] Aumont V., Larronde F., Richard T., Budzinski H., Decendit A., Deffieux G., Krisa S. and Mérillon J.-M. Production of highly 13C-labeled polyphenols in Vitis vinifera cell bioreactor cultures. Journal of Biotechnology. 2004; 109(3) 287-294

[191] Socaciu C. Natural pigments as food colorants. In: C Socaciu (Ed.) Food colorants, chemical and functional properties. New York: CRC Press. 2008. pp583-603.

[192] Mortensen A. Carotenoids and other pigments as natural colorants. Pure and Applied Chemistry 2006; 78(8) 15

[193] Schürch C., Blum P. and Zülli F. Potential of plant cells in culture for cosmetic application. Phytochemistry Reviews. 2008; 7(3) 599-605 
